\title{
6. CENOZOIC SILICEOUS FLAGELLATES FROM THE FRAM STRAIT AND THE EAST GREENLAND MARGIN: BIOSTRATIGRAPHIC AND PALEOCEANOGRAPHIC RESULTS ${ }^{1}$
}

\author{
Sigurd Locker ${ }^{2}$
}

\begin{abstract}
More than 110 taxa of siliceous flagellates including silicoflagellates, ebridians, actiniscidians, and synuraceans are tabulated from Cenozoic sediments of Holes 908A and 913B. The assemblages investigated from Hole 908A, Fram Strait, are assigned to the upper Oligocene Cannopilus hemisphaericus Zone of silicoflagellates. The assemblages studied from Hole 913B, East Greenland margin, yielded in the upper part the middle Miocene Spongebria miocenica Zone of ebridians and in the lower part the middle to upper Eocene Corbisema hexacantha Zone of silicoflagellates.

The assemblages of siliceous flagellates demonstrate that a permanent surface-water exchange may have existed between the Norwegian-Greenland Sea, the Arctic Ocean, and probably also the Barents Sea during Eocene and Oligocene times. Minor input of surface-water from the North Atlantic is indicated by certain silicoflagellates for late Oligocene time.

Several taxa of silicoflagellates and ebridians were recognized as new, but most of them are treated with open nomenclature. Only 3 ebridian species that characterize middle to upper Eocene and upper Oligocene assemblages are formally introduced as new: Ebriopsis acuta, Hermesinella paraconata, and Hermesinum acus.
\end{abstract}

\section{INTRODUCTION}

During Ocean Drilling Program Leg 151, seven sites were occupied in the Norwegian-Greenland Sea and the Arctic Ocean. The sites were located in four regions (Fig. 1) to investigate the paleoceanographic, paleoclimatic, and biotic evolution of the boreal, subarctic, and arctic realms (Myhre, Thiede, Firth, et al., 1995). The study of paleoceanography was especially addressed to the development of the northern and southern gateways that connect the NorwegianGreenland Sea in the present with adjacent oceanic regions, (i.e. the Arctic Ocean in the north and the North Atlantic in the south). Investigations of siliceous plankton groups may help to understand when and in what manner the northern and southern gateways, the Fram Strait and the Greenland-Scotland Ridge, allowed continuous surface-water exchange.

The history of the Norwegian-Greenland Sea as a deep-water connection between the Arctic Ocean and the North Atlantic commenced in early Eocene time (Eldholm et al., 1989). Siliceous plankton species documenting this early phase of paleoceanographic evolution were recovered during previous DSDP/ODP legs only at a few sites (Talwani, Udintsev, et al., 1976; Eldholm, Thiede, Taylor, et al., 1989). Hence, the recovery of Paleogene sediments at Sites 908 and 913, enabling high-resolution studies of siliceous flagellates, is of great importance.

In this paper, silicoflagellates are used to establish a continuous biostratigraphy from the lower Eocene to the Quaternary (Table 1; Fig. 2) and to determine the stratigraphic position of Paleogene biosilica-bearing sediments in Holes 908A and 913B (Tables 2, 4). Since ebridian data are insufficient for the Paleogene, only informal assemblages are designated and are correlated to silicoflagellate zones (Tables 3,5). The stratigraphy of Miocene sediments in Hole 913B is determined solely by ebridians (Table 4).

'Thiede, J., Myhre, A.M., Firth, J.V., Johnson, G.L., and Ruddiman, W.F. (Eds.), 1996. Proc. ODP, Sci. Results, 151: College Station, TX (Ocean Drilling Program)

${ }^{2}$ Christian-Albrechts-Universität, Sonderforschungsbereich 313, Heinrich-HechtPlatz 10, D-24118 Kiel, Federal Republic of Germany. (Present address: GEOMAR Research Center for the Marine Geosciences, Wischhofstraße 1-3, D-12418, Kiel, Federal Republic of Germany.) slocker@ geomar.de

\section{METHODS}

Sediment samples totalling 235 were treated from Holes 908A and $913 \mathrm{~B}$ to investigate Cenozoic silicoflagellates, ebridians, and other siliceous flagellates. Usually one sample per section was taken, but from the deeper part of Hole 913B only two samples per core were used. To concentrate the skeletons, samples were successively processed with hydrogen peroxide, hydrochloric acid, and sodium pyrophosphate. After the use of acid and lye, samples were washed three times. The decalcified residues were strewn on cover glasses 22 $\times 22 \mathrm{~mm}$ in size and embedded in Canada balsam on glass slides.

Generally, eight traverses across a cover glass $(21 \%)$ were counted with a magnification of $390 \times$ and tabulated for species abundances. In many cases, more traverses were scanned to recognize rare but indicative species. The following abundance classes were used: $\mathrm{B}=$ barren; $\mathrm{T}=$ traces, specimens out of count; $\mathrm{R}=$ rare, $1-5$ specimens; $\mathrm{F}=$ few, $6-15$ specimens $; \mathrm{C}=$ common, $16-50$ specimens; $\mathrm{A}=$ abundant, $>50$ specimens. Special assumptions were made for certain taxa. If complete skeletons of Naviculopsis species were missing, fragments were indicated as $\mathrm{P}=$ present. Because small specimens of Hovassebria brevispinosa can be easily confused with triodes, all skeletons were indicated only as $\mathrm{P}=$ present. Although noted during the counting process, isolated triodes and triaenes were neglected in tables.

Since siliceous flagellates are minor constituents of the plankton assemblages, diatom frequencies were estimated as an indicator for expected abundances of siliceous flagellates. Diatom abundances were referred to the decalcified residue and noted as percent coverage of the viewing field. The following abundance classes were adopted: $\mathrm{B}=$ barren; $\mathrm{T}=$ traces, single valves and/or remnants of corrosion, generally $<1 \%$ of coverage; $\mathrm{R}=$ rare, $1 \%-5 \% ; \mathrm{F}=$ few, $6 \%-15 \% ; \mathrm{C}$ $=$ common, $16 \%-50 \% ; \mathrm{A}=$ abundant, $>50 \%$.

The preservation of skeletons was indicated as follows: $\mathrm{P}=$ poor, specimens are fragmented or strongly corroded; $M=$ moderate, specimens show minor signs of fragmentation or corrosion; $\mathrm{G}=$ good, specimens are not fragmented or corroded. Because an assemblage may exhibit all stages of preservation ranging from poor to good, the preservation is usually indicated by two letters. The first letter gives the most frequent category, the second one the next frequent category. 


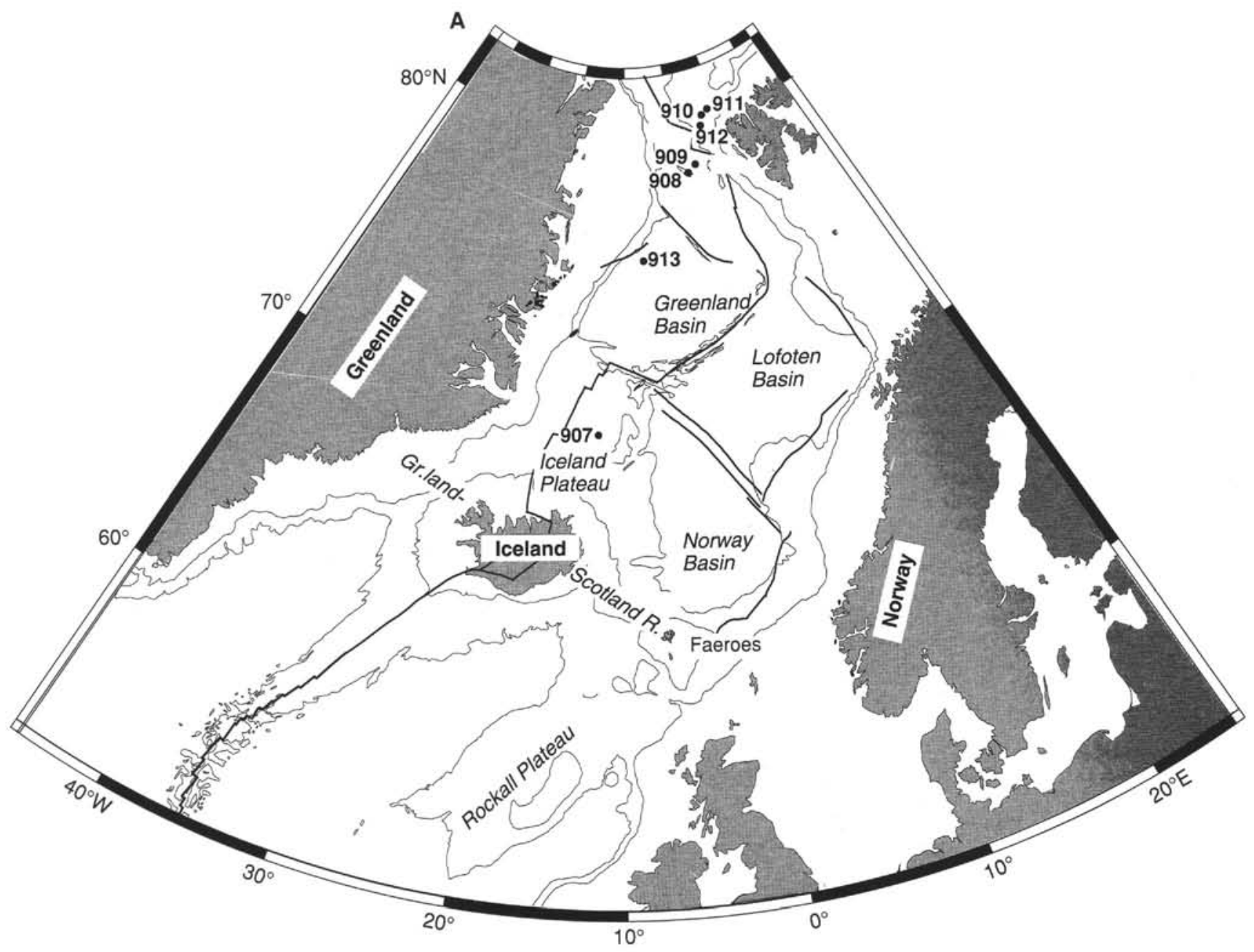

Figure 1. Location of Leg 151 sites in the Norwegian-Greenland Sea and in the Arctic Ocean.

The sediment sequences studied are placed into silicoflagellate zones which are delimited by certain bioevents (Table 1; Fig. 2). The silicoflagellate events, that is, the first and last occurrences (FO, LO) of particular species, are referred to the paleomagnetic time scale of Cande and Kent (1992) and to the recalculated nannoplankton ages of Wei and Peleo-Alampay (1993). The events are preferably related to the North Atlantic and Norwegian-Greenland Sea realms to avoid bioprovincially biased data. Since no ebridian zones are available for the Paleogene at present, the assemblages found are correlated to silicoflagellate zones. This enables indirect correlation to the calcareous nannoplankton zonation of Martini (1971).

\section{SILICOFLAGELLATE EVENTS}

The silicoflagellate zonation used for ODP Leg 151 is based on the set of events displayed in Table 1 and Figure 2. The Neogene zonation corresponds to that described by Locker and Martini (1989) and the Paleogene zonation mainly to that introduced by Bukry (1981b). The Neogene zonation is well established both in the Atlantic and Pacific Oceans. Only minor changes must be introduced to get a better fit with the nannoplankton zonations of Martini (1971) and Okada and Bukry (1980). The Paleogene zonation is rather loosely defined in certain parts, because biosilica-bearing sediments of that age are predominantly represented only in short sequences. The set of events that establishes the silicoflagellate zonation of ODP Leg 151 is described from base to top.

\section{FO of Naviculopsis robusta}

Although the Naviculopsis robusta Zone has a wide geographic range in former epicontinental seas of Russia (Glezer, 1970), this zone seems to represent more oceanic conditions in the North Atlantic realm (Bukry, 1978b). The first occurrence (FO) of $N$. robusta correlates in DSDP Hole 390A (Bukry, 1978b), Northwest Atlantic, with nannoplankton Zone CP10 of Okada and Bukry $(1980)=$ Zone NP12 of Martini (1971). The overlying Corbisema spinosa Zone starts with Zone CP11 = Zone NP13. The base of Zone CP10 has an age of 52.5 Ma (Wei and Peleo-Alampay, 1993).

\section{FO of Corbisema spinosa}

The Corbisema spinosa Zone is known from many holes of the Atlantic and Pacific Oceans. The FO of C. spinosa ranges from Zone $\mathrm{CP} 11$ to CP13b $=$ Zone NP13 to NP15. The lowest occurrence is in Hole 390A (Bukry, 1978b), Northwest Atlantic, and belongs to Zone $\mathrm{CP} 11=$ Zone NP13. The base of Zone CP11 has an age of $50.5 \mathrm{Ma}$ (Wei and Peleo-Alampay, 1993).

\section{FO of Corbisema hexacantha}

The Corbisema hexacantha Zone is described from several holes in the Atlantic and Pacific Oceans. The FO of $C$. hexacantha displays a considerable range, which may be due to the short intervals usually recovered. The lowest occurrence is found in DSDP Hole 386 
Table 1. Cenozoic silicoflagellate events, adopted occurrences in North Atlantic and Norwegian-Greenland Sea holes, and ages. Paleomagnetic data are from Bleil (1989), ages are from Wei and Peleo-Alampay (1993).

\begin{tabular}{|c|c|c|c|c|}
\hline Epoch & & Silicoflagellate event & Norwegian-Greenland Sea & $\begin{array}{l}\text { Age } \\
(\mathrm{Ma})\end{array}$ \\
\hline Quaternary & $\begin{array}{l}\text { LO } \\
\text { FCO } \\
\text { FO }\end{array}$ & $\begin{array}{l}\text { Mesocena quadrangula } \\
\text { Mesocena quadrangula } \\
\text { Distephanus speculum octonarius }\end{array}$ & $\begin{array}{l}\text { 644A: uppermost } \mathrm{C} 1 \mathrm{r} \cdot 1 \mathrm{r}=\text { upper NN19B } \\
\text { 644A: C1r.1n = middle NN19B } \\
\text { 644A: uppermost } \mathrm{C} 1 \mathrm{r} \cdot 2 \mathrm{r}=\mathrm{NN} 19 \mathrm{~B}\end{array}$ & $\begin{array}{l}0.8 \\
1.0\end{array}$ \\
\hline Pliocene & $\begin{array}{l}\text { LO } \\
\text { LO } \\
\text { LO } \\
\text { LO } \\
\text { LO } \\
\text { LO } \\
\text { FO }\end{array}$ & $\begin{array}{l}\text { Distephanus aculeatus } \\
\text { Mesocena diodon } \\
\text { Paramesocena circulus apiculata } \\
\text { Cannopilus depressus } \\
\text { Corbisema triacantha } \\
\text { Distephanus stauracanthus } \\
\text { Distephanus stauracanthus }\end{array}$ & $\begin{array}{l}\text { 644A: uppermost } \mathrm{C} 2 \mathrm{An} .1 \mathrm{n}=\text { upper } \mathrm{NN} 16 \\
\text { 642C: C } 3 \mathrm{An} .1 \mathrm{n}=\text { lower } \mathrm{NN} 12 \\
\text { 642C: } \mathrm{C} 3 \mathrm{Ar}=\text { middle NN11B } \\
\text { 408: top NN7 } \\
\text { 408: middle NN7 } \\
\text { 642C: top NN6 } \\
\text { 642C: middle NN6 }\end{array}$ & $\begin{array}{r}3.2 \\
5.8 \\
6.4 \\
11.2 \\
12.2 \\
13.2 \\
13.8\end{array}$ \\
\hline Miocene & $\begin{array}{l}\text { FO } \\
\text { FO } \\
\text { LO } \\
\text { FO } \\
\text { FO } \\
\text { FO }\end{array}$ & $\begin{array}{l}\text { Paramesocena circulus apiculata } \\
\text { Mesocena diodon } \\
\text { Naviculopsis } \\
\text { Naviculopsis navicula } \\
\text { Naviculopsis iberica } \\
\text { Naviculopsis lata }\end{array}$ & $\begin{array}{l}\text { 642C: } N \text { N6 } \\
\text { 642C: C5ADr }=\text { upper NN5 } \\
\text { 642D: lower C5En = uppermost NN2 } \\
\text { 642D: C6An. } 1 \mathrm{n}=\text { middle NN2 } \\
\text { 642D: C6An. } 1 \mathrm{r}=\text { middle NN2 } \\
\text { 369A } 407: \text { base NN1 }\end{array}$ & $\begin{array}{l}14.7 \\
18.8 \\
20.7 \\
20.9 \\
24.0\end{array}$ \\
\hline Oligocene & $\begin{array}{l}\text { FO } \\
\text { LO } \\
\text { LO }\end{array}$ & $\begin{array}{l}\text { Cannopilus hemisphaericus } \\
\text { Corbisema apiculata } \\
\text { Corbisema hexacantha }\end{array}$ & $\begin{array}{l}\text { 338: middle NP24 } \\
\text { 369A: top CP16c }=\text { top NP22 } \\
612: \text { middle CP15b }=\text { middle } \mathrm{NP} 19 / 20\end{array}$ & $\begin{array}{l}27.8 \\
32.4 \\
34.7\end{array}$ \\
\hline Eocene & $\begin{array}{l}\text { FO } \\
\text { FO } \\
\text { FO }\end{array}$ & $\begin{array}{l}\text { Corbisema hexacantha } \\
\text { Corbisema spinosa } \\
\text { Naviculopsis robusta }\end{array}$ & $\begin{array}{l}\text { 386: middle CP13c }=\text { upper NP15 } \\
\text { 390A: base CP11 = NP13 } \\
\text { 390A: base CP10 = NP12 }\end{array}$ & $\begin{array}{l}44.2 \\
50.5 \\
52.5\end{array}$ \\
\hline
\end{tabular}

(Bukry, 1978c), Northwest Atlantic, and correlates to Zone CP13c $=$ upper Zone NP15. This is in accordance with data from the Kellogg Shale, California, where the FO is also found in Zone CP13c = upper Zone NP15 (Bukry in Barron et al., 1984). Here an intermediate age of 44.2 Ma is adopted for the middle of Zone CP13c (Wei and PeleoAlampay, 1993).

\section{LO of Corbisema hexacantha}

The last occurrence (LO) of $C$. hexacantha is detected in several holes of the Atlantic and Pacific Oceans, but is often poorly defined by nannoplankton correlations. In DSDP Hole 406 (Bukry, 1985a), North Atlantic, the LO of this species occurs within Zones NP19/20 (Müller, 1979). In DSDP Hole 612 (Bukry, 1987), Northwest Atlantic, the LO occurs in the middle of Zone CP15b = Zones NP19/20. Here an intermediate age of $34.7 \mathrm{Ma}$ is adopted for the middle of Zone CP15b (Wei and Peleo-Alampay, 1993).

\section{LO of Corbisema apiculata}

The Corbisema apiculata Zone straddles the Eocene to Oligocene transition, which is characterized by a decline of species diversities and abundances in most regions. Since biosiliceous sediments of early Oligocene age are rarely recovered both in the Atlantic and Pacific Oceans, stratigraphical resolution is generally poorer for this interval. Reworking may also mask the LO of $C$. apiculata in many holes. The best correlation seems to be in DSDP Hole 369A, Northeast Atlantic (Bukry, 1978a), where the last common and consistent occurrence is in Zone CP16c = Zone NP22. Hence, the LO of C. apiculata is tentatively placed at the top of Zone CP16c, corresponding to an age of 32.4 Ma (Wei and Peleo-Alampay, 1993).

\section{FO of Cannopilus hemisphaericus}

The FO of $C$. hemisphaericus delimits the top of the Naviculopsis biapiculata Zone, which is a rather undifferentiated lower to upper Oligocene silicoflagellate zone. The FO simultaneously marks the base of the Cannopilus hemisphaericus Zone, which is sometimes noted as Distephanus speculum haliomma Zone (Bukry, 1981b; Perch-Nielsen, 1985). The FO of $C$. hemisphaericus occurs in Hole 369A (Bukry, 1978a), Northeast Atlantic, in Zone CP19b = Zone NP25. In DSDP Hole 338 (Martini and Müller, 1976), Norwegian
Sea, the FO is found in Zones NP24/25 (new interpretation) and in Hole 406 (Bukry, 1985a), North Atlantic, in Zone NP24 (Müller, 1979). According to the joint occurrence of $C$. hemisphaericus and Discolithina desueta in Hole 338 (Müller, 1976), the FO of $C$. hemisphaericus may really be in Zone NP24 (see Müller, 1970). Acknowledging these results, the FO of $C$. hemisphaericus may be placed at the base of Zone NP25 or, tentatively, in the middle of Zone NP24. Here the latter datum is preferred, corresponding to an age of 27.8 Ma (Wei and Peleo-Alampay, 1993).

\section{FO of Naviculopsis lata}

The Naviculopsis lata Zone is well known from several sites in the Atlantic and Pacific Oceans. The FO of $N$. lata lies in Hole 369A (Bukry, 1978a), Northeast Atlantic, possibly in Zone CP19b = Zone NP25. In DSDP Hole 407 (Martini, 1979), North Atlantic, the FO is in the middle of Zone NN1. Assuming an intermediate level, the base of Zone NN1 can be adopted as the datum plane, corresponding to an age of 24.0 Ma (Wei and Peleo-Alampay, 1993).

\section{FO of Naviculopsis navicula}

The Naviculopsis navicula Zone ranges from the FO of $N$. navicula to the LO of $N$. quadratum and all Naviculopsis species, respectively. The FO of $N$. navicula is precisely indicated in Chron C6An.1n of DSDP Hole 642C, Norwegian Sea (Locker and Martini, 1989; Bleil, 1989). This correlates with the middle of Zone NN2 and an age of 20.7 Ma (recalculated from Locker and Martini, 1989).

\section{LO of all Naviculopsis species}

The LO of all Naviculopsis species lies in Hole 407 (Martini, 1979), North Atlantic, in upper Zones $\mathrm{CN} 1 \mathrm{~b} / 2=$ Zones NN1/3 (Bukry, 1979). In Hole 642C, Norwegian Sea, the LO is in lower Chron C5En (Locker and Martini, 1989; Bleil, 1989), which approximates the top of Zone NN2. The top of Zone NN2 has an age of 18.7 Ma (Wei and Peleo-Alampay, 1993).

\section{FO of Mesocena diodon}

In many holes, the very distinctive FO of $M$. diodon subdivides the Corbisema triacantha Zone into a lower and an upper part. The 


\section{S. LOCKER}

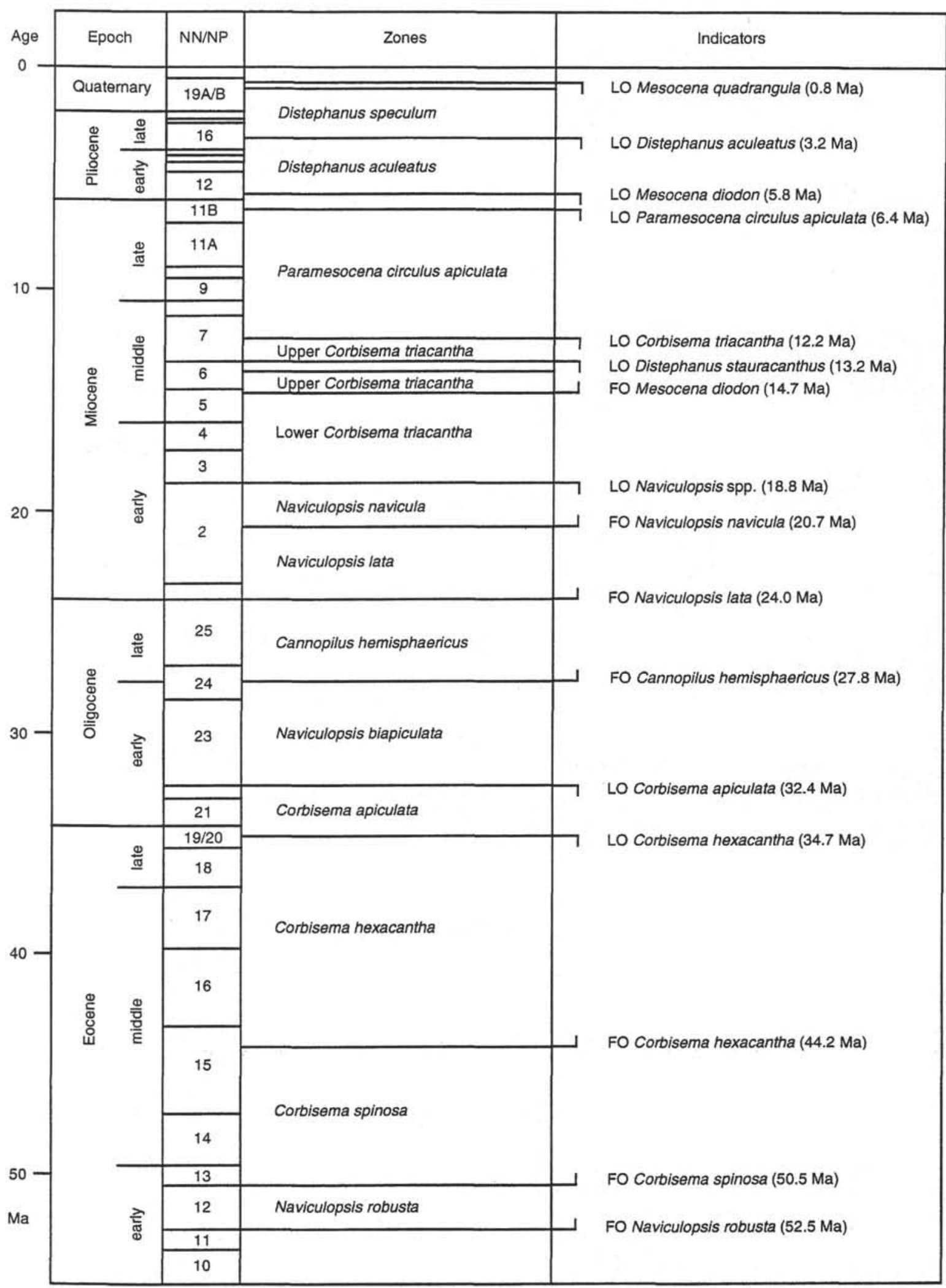

Figure 2. Silicoflagellate zonation of the Cenozoic used for ODP Leg 151, first and last occurrences (FO, LO) of diagnostic species, and correlation to the nannoplankton zonation of Martini (1971). Ages are from Wei and Peleo-Alampay (1993). 
Table 2. Hole 908A, stratigraphic distribution of silicoflagellates in upper Oligocene and Miocene-Pliocene sediments.

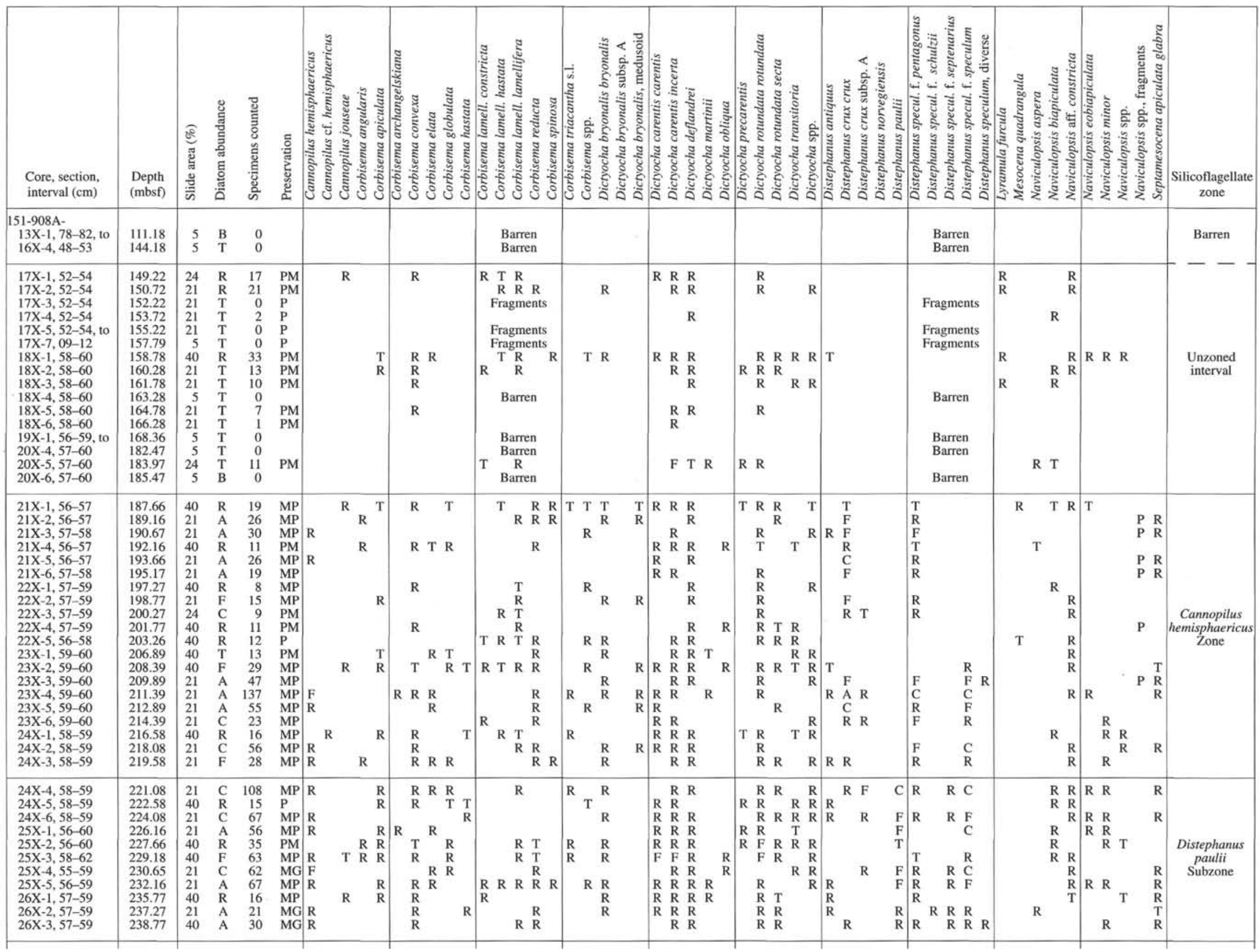


Table 2 (continued).

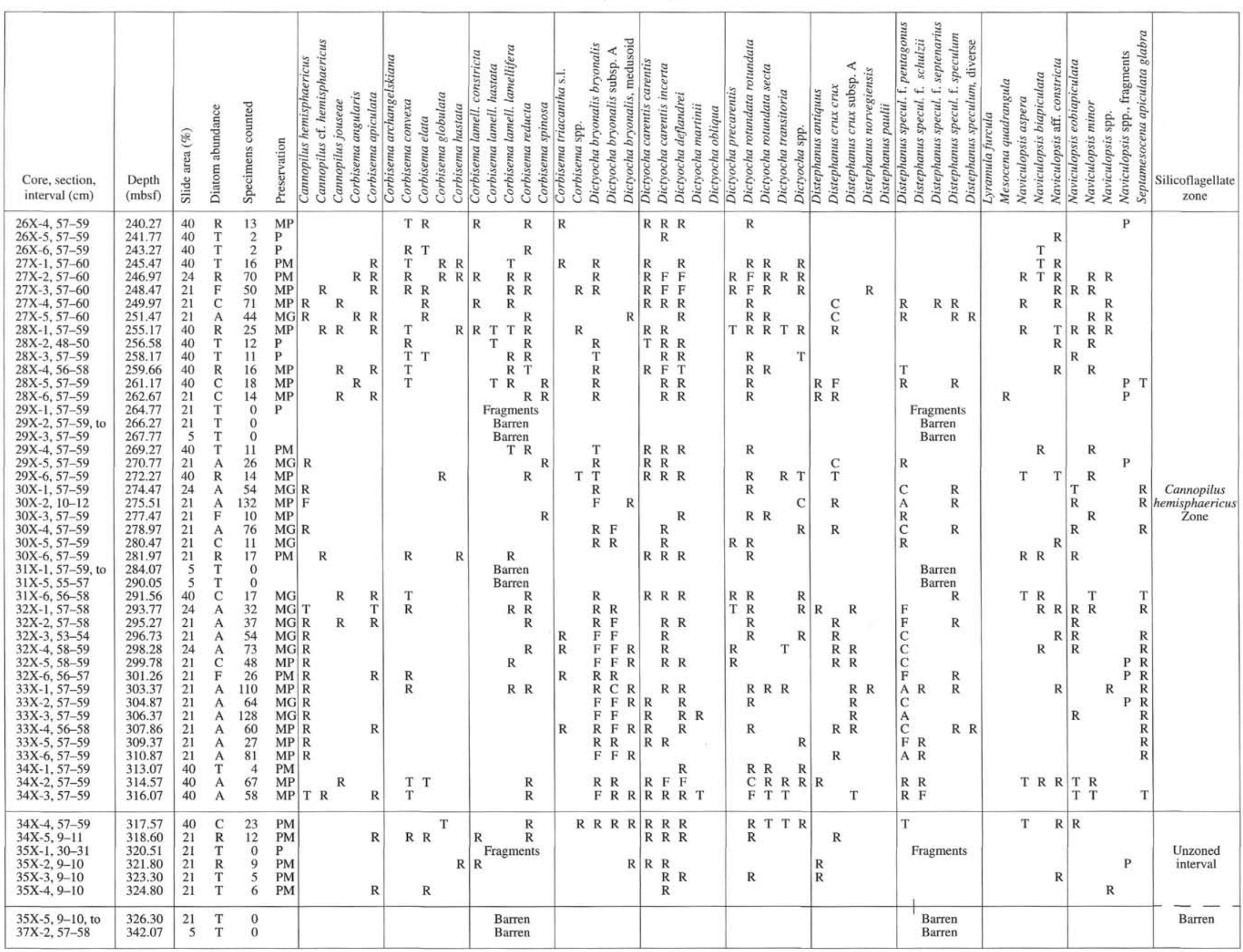

Note: For definition of species abundance and preservation, see text. 
Table 3. Hole 908A, stratigraphic distribution of ebridians, actiniscidians, and synuraceans in upper Oligocene and Miocene-Pliocene sediments.

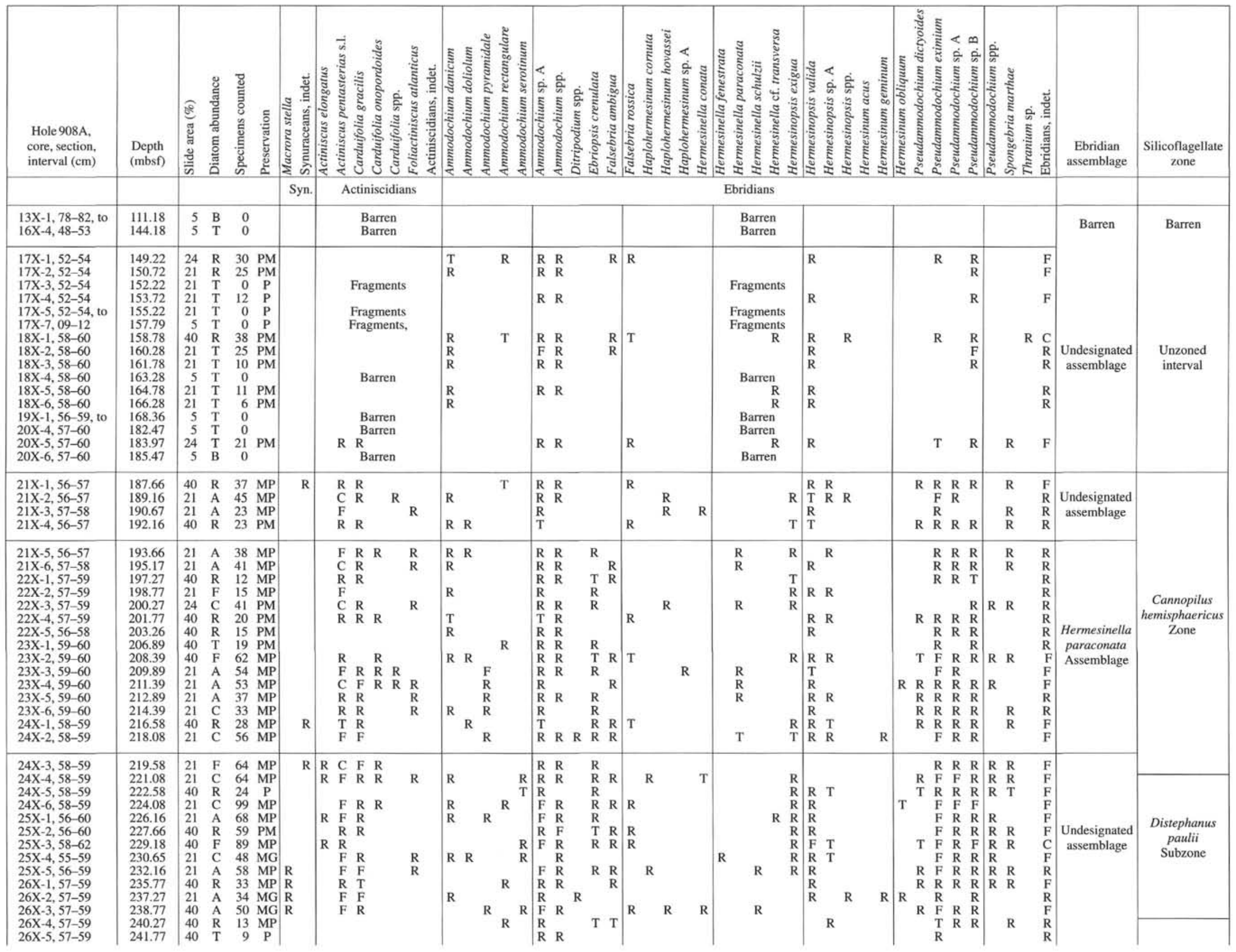


Table 3 (continued).

\begin{tabular}{|c|c|c|c|c|c|c|c|c|c|c|c|c|c|c|c|c|c|c|c|c|c|c|c|c|c|c|c|c|c|c|c|c|c|c|}
\hline $\begin{array}{l}\text { Hole 908A, } \\
\text { core, section, } \\
\text { interval }(\mathrm{cm})\end{array}$ & $\begin{array}{l}\text { Depth } \\
\text { (mbsf) }\end{array}$ & 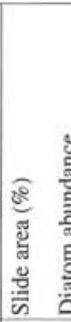 & 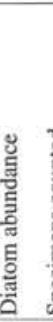 & 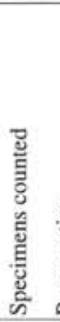 & 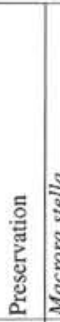 & 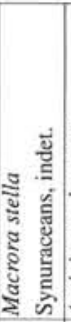 & 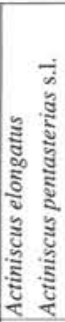 & 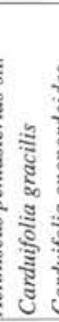 & 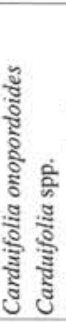 & 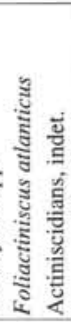 & & 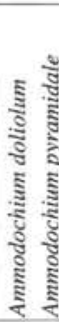 & 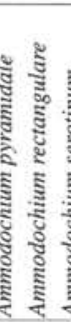 & & & & 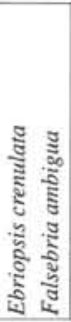 & & 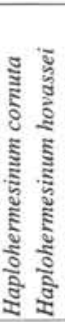 & & & 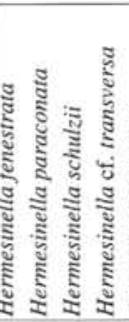 & 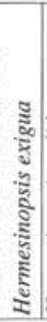 & & 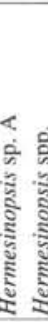 & 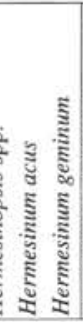 & & 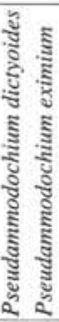 & 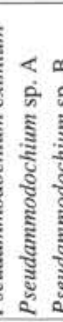 & 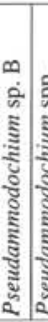 & & & $\begin{array}{c}\text { Ebridian } \\
\text { assemblage }\end{array}$ & $\begin{array}{l}\text { Silicoflagellate } \\
\text { zone }\end{array}$ \\
\hline $\begin{array}{l}26 \mathrm{X}-6,57-59 \\
27 \mathrm{X}-1,57-60 \\
27 \mathrm{X}-2,57-60 \\
27 \mathrm{X}-3,57-60 \\
27 \mathrm{X}-4,57-60 \\
27 \mathrm{X}-5,57-60 \\
28 \mathrm{X}-1,57-59 \\
28 \mathrm{X}-2,48-50 \\
28 \mathrm{X}-3,57-59 \\
28 \mathrm{X}-4,56-58\end{array}$ & $\begin{array}{l}243.27 \\
245.47 \\
246.97 \\
248.47 \\
249.97 \\
251.47 \\
255.17 \\
256.58 \\
258.17 \\
259.66\end{array}$ & $\begin{array}{ll}40 & \\
40 & 1 \\
24 & 1 \\
21 & 1 \\
21 & \\
21 & \\
40 & 1 \\
40 & 1 \\
40 & 1 \\
40 & \mathrm{~F}\end{array}$ & $\begin{array}{l}\mathrm{T} \\
\mathrm{T} \\
\mathrm{R} \\
\mathrm{R} \\
\mathrm{C} \\
\mathrm{C} \\
\mathrm{A} \\
\mathrm{R} \\
\mathrm{T} \\
\mathrm{T} \\
\mathrm{T} \\
\mathrm{R}\end{array}$ & $\begin{array}{rl}6 & \\
20 & \mathrm{P} \\
87 & \mathrm{P} \\
59 & 1 \\
51 & 1 \\
24 & \mathrm{~N} \\
29 & 1 \\
12 & \\
10 \\
45\end{array}$ & \begin{tabular}{c|} 
P \\
PM \\
PM \\
MP \\
MP \\
MG \\
MP \\
P \\
P \\
MP
\end{tabular} & $R$ & $\begin{array}{l}\mathrm{R} \\
\mathrm{R} \\
\mathrm{F} \\
\mathrm{R}\end{array}$ & $\mathrm{R}$ & & $\begin{array}{l}\mathrm{R} \\
\mathrm{R}\end{array}$ & $\begin{array}{l}\mathrm{R} \\
\mathrm{R} \\
\mathrm{R}\end{array}$ & $\begin{array}{l}\mathrm{R} \\
\mathrm{R} \\
\mathrm{R} \quad \mathrm{R} \\
\mathrm{R}\end{array}$ & $R^{R}$ & & $\begin{array}{ll}R & F \\
R & F \\
F & F \\
R & F \\
R & F \\
R & F \\
F & F \\
R & F \\
R & \\
R & F\end{array}$ & & $\begin{array}{ll}\mathrm{R} & \\
& \\
\mathrm{R} & \mathrm{R} \\
& \mathrm{R} \\
\mathrm{R} & \mathrm{T}\end{array}$ & $\begin{array}{l}\mathrm{R} \\
\mathrm{R} \\
\mathrm{R} \\
\mathrm{R} \\
\mathrm{T}\end{array}$ & R & & & & $\begin{array}{l}\mathrm{R} \\
\mathrm{R} \\
\mathrm{R}\end{array}$ & $\begin{array}{l}\mathrm{T} \\
\mathrm{R} \\
\mathrm{R} \\
\mathrm{R} \\
\mathrm{R} \\
\mathrm{R}\end{array}$ & $\begin{array}{ll}\mathrm{R} & \mathrm{R} \\
\mathrm{R} & \\
\mathrm{R} & \end{array}$ & & & $\begin{array}{ll}\mathrm{R} & \mathrm{R} \\
\mathrm{R} & \mathrm{F} \\
\mathrm{R} & \mathrm{F} \\
\mathrm{R} & \mathrm{R} \\
& \mathrm{R} \\
\mathrm{R} & \mathrm{R} \\
\mathrm{R} & \mathrm{R} \\
& \mathrm{R} \\
\mathrm{R} & \mathrm{R}\end{array}$ & $\begin{array}{l}\mathrm{R} \\
\mathrm{F} \\
\mathrm{R} \\
\mathrm{R} \\
\mathrm{R} \\
\mathrm{R}\end{array}$ & \begin{tabular}{l|l} 
& $F$ \\
$\mathrm{~F}$ & $\mathrm{~F}$ \\
$\mathrm{~F}$ & \\
$\mathrm{R}$ & \\
$\mathrm{R}$ & $\mathrm{F}$ \\
$\mathrm{R}$ & \\
$\mathrm{F}$ & $\mathrm{F}$
\end{tabular} & $\begin{array}{ll}R & R \\
R & R \\
& R \\
& R \\
R & R \\
R & R \\
& \\
R & T\end{array}$ & $\begin{array}{l}R \\
R \\
C \\
F \\
F \\
R \\
R \\
R \\
R \\
\text { F }\end{array}$ & \begin{tabular}{|l} 
Undesignated \\
assemblage \\
and
\end{tabular} & \multirow{4}{*}{$\begin{array}{c}\text { Cannopilus } \\
\text { hemisphaericus } \\
\text { Zone }\end{array}$} \\
\hline $\begin{array}{l}28 X-5,57-59 \\
28 X-6,57-59\end{array}$ & $\begin{array}{l}261.17 \\
262.67\end{array}$ & $\begin{array}{l}40 \\
21\end{array}$ & $\begin{array}{l}\mathrm{C} \\
\mathrm{C}\end{array}$ & $\begin{array}{l}41 \\
39\end{array}$ & $\begin{array}{l}\text { MP } \\
\text { MP }\end{array}$ & & & $\begin{array}{l}\mathrm{R} \\
\mathrm{R}\end{array}$ & & & $\mathrm{R}$ & $R$ & $\mathrm{R}$ & & $R_{F}$ & & $\begin{array}{l}\mathrm{R} \\
\mathrm{R}\end{array}$ & & & & & $\mathrm{T}$ & & & & $\begin{array}{l}\mathrm{F} \\
\mathrm{R}\end{array}$ & R & $\begin{array}{l}\mathrm{R} \\
\mathrm{F}\end{array}$ & $\mathrm{R}$ & & $\mathrm{R}$ & $\begin{array}{l}F \\
F\end{array}$ & $\begin{array}{c}\text { Hermesinum } \\
\text { acus } \\
\text { Assemblage }\end{array}$ & \\
\hline $\begin{array}{l}29 X-1,57-59 \\
29 X-2,57-59, \text { to } \\
29 X-3,57-59 \\
29 X-4,57-59 \\
29 X-5,57-59 \\
29 X-6,57-59 \\
30 X-1,57-59 \\
30 X-2,10-12 \\
30 X-3,57-59 \\
30 X-4,57-59 \\
30 X-5,57-59 \\
30 X-6,57-59 \\
31 X-1,57-59, \text { to } \\
31 X-5,55-57 \\
31 X-6,56-58 \\
32 X-1,57-58 \\
32 X-2,57-58 \\
32 X-3,53-54 \\
32 X-4,58-59 \\
32 X-5,58-59 \\
32 X-6,56-57 \\
33 X-1,57-59 \\
33 X-2,57-59 \\
33 X-3,57-59 \\
33 X-4,56-58 \\
33 X-5,57-59 \\
33 X-6,57-59 \\
34 X-1,57-59\end{array}$ & $\begin{array}{l}264.77 \\
266.27 \\
267.77 \\
269.27 \\
270.77 \\
272.27 \\
274.47 \\
275.51 \\
277.47 \\
278.97 \\
280.47 \\
281.97 \\
284.07 \\
290.05 \\
291.56 \\
293.77 \\
295.27 \\
296.73 \\
298.28 \\
299.78 \\
301.26 \\
303.37 \\
304.87 \\
306.37 \\
307.86 \\
309.37 \\
310.87 \\
313.07\end{array}$ & $\begin{array}{rr}21 & \\
21 & \\
5 & 1 \\
40 & \\
21 & \\
40 & \\
24 & \\
21 & \\
21 & 1 \\
21 & \\
21 & \\
21 & 1 \\
5 & 7 \\
5 & \\
40 & \\
24 & \\
21 & \\
21 & \\
24 & \\
21 & \\
21 & \\
21 & \\
21 & \\
21 & \\
21 & \\
21 & \\
21 & \\
40 & \end{array}$ & $\begin{array}{l}\text { T } \\
\text { T } \\
\text { T } \\
\text { T } \\
\text { A } \\
\text { R } \\
\text { A } \\
\text { A } \\
\text { F } \\
\text { A } \\
\text { C } \\
\text { R } \\
\text { T } \\
\text { T } \\
\text { C } \\
\text { A } \\
\text { A } \\
\text { A } \\
\text { A } \\
\text { C } \\
\text { F } \\
\text { A } \\
\text { A } \\
\text { A } \\
\text { A } \\
\text { A } \\
\text { A } \\
\text { T }\end{array}$ & $\begin{array}{rl}12 & \\
0 & \\
0 & \\
21 & \mathrm{P} \\
45 & \mathrm{~N} \\
25 & \mathrm{~N} \\
19 & \mathrm{~N} \\
27 & \mathrm{~N} \\
43 & \mathrm{~N} \\
69 & \mathrm{~N} \\
33 & \mathrm{~N} \\
27 & \mathrm{P} \\
0 & \\
0 & \\
47 & \mathrm{~N} \\
20 & \mathrm{~N} \\
37 & \mathrm{~N} \\
43 & \mathrm{~N} \\
55 & \mathrm{~N} \\
54 & \mathrm{~N} \\
19 & \mathrm{1} \\
56 & \mathrm{~N} \\
35 & \mathrm{~N} \\
44 & \mathrm{~N} \\
30 & \mathrm{~N} \\
18 & \mathrm{~N} \\
36 & \mathrm{~N} \\
9 & \mathrm{I}\end{array}$ & \begin{tabular}{l|l} 
P & \\
PM & MG \\
MP & MG \\
MP & MP \\
MG & MG \\
PM & \\
& \\
MG & MG \\
MG & MG \\
MG & \\
MP & PM \\
MP \\
MG \\
MG \\
MP \\
MP \\
MP \\
PM
\end{tabular} & $\begin{array}{l}\mathrm{R} \\
\mathrm{R} \\
\mathrm{R} \\
\mathrm{R} \\
\mathrm{R} \\
\mathrm{F} \\
\mathrm{F}\end{array}$ & $\begin{array}{r}\mathrm{R} \\
\\
\\
\mathrm{F} \\
\mathrm{R} \\
\mathrm{F} \\
\mathrm{F} \\
\mathrm{F} \\
\mathrm{F} \\
\mathrm{F} \\
\mathrm{C} \\
\end{array}$ & $\begin{array}{l}\mathrm{R} \\
\text { Frag } \\
\mathrm{Ba} \\
\mathrm{F} \\
\mathrm{F} \\
\mathrm{R} \\
\mathrm{R} \\
\mathrm{R} \\
\mathrm{R} \\
\mathrm{R} \\
\mathrm{Ba} \\
\mathrm{Ba} \\
\mathrm{Ba} \\
\mathrm{R} \\
\mathrm{R} \\
\mathrm{F} \\
\mathrm{F} \\
\mathrm{F} \\
\mathrm{C} \\
\mathrm{R} \\
\mathrm{F} \\
\mathrm{R} \\
\mathrm{F} \\
\mathrm{R} \\
\mathrm{R} \\
\mathrm{R} \\
\mathrm{R}\end{array}$ & $\begin{array}{l}\text { Iments } \\
\text { arren } \\
\mathrm{T} \\
\mathrm{R}\end{array}$ & $\begin{array}{l}\mathrm{R} \\
\mathrm{T} \\
\mathrm{R} \\
\mathrm{R} \\
\mathrm{R} \\
\mathrm{R} \\
\mathrm{R} \\
\mathrm{R} \\
\mathrm{R} \\
\mathrm{R}\end{array}$ & $\begin{array}{l}\mathrm{R} \\
\mathrm{R}\end{array}$ & $\begin{array}{ll} & \mathrm{R} \\
& \mathrm{T} \\
& \mathrm{R} \\
\mathrm{R} & \mathrm{R} \\
\mathrm{R} & \mathrm{R} \\
& \mathrm{R} \\
& \\
\mathrm{R}\end{array}$ & $\begin{array}{ll}\mathrm{R} & \mathrm{T} \\
\mathrm{R} & \\
\mathrm{R} & \\
\mathrm{R} & \\
\mathrm{R} & \\
\mathrm{R} & \\
\mathrm{R} & \\
\mathrm{R} & \\
& \\
& \\
\mathrm{R} & \mathrm{R} \\
\mathrm{R} & \\
\mathrm{R} & \\
\mathrm{R} & \end{array}$ & \begin{tabular}{l|l}
$\mathrm{R}$ \\
$\mathrm{R}$ \\
$\mathrm{R}$ \\
$\mathrm{R}$ \\
$\mathrm{R}$ \\
$\mathrm{R}$ & $\mathrm{R}$ \\
$\mathrm{R}$ \\
$\mathrm{R}$ \\
$\mathrm{R}$ \\
$\mathrm{F}$
\end{tabular} & $\begin{array}{lll}R & \\
R & F \\
R & F \\
R & \\
R & \\
R & F \\
R & F \\
& F \\
F & F\end{array}$ & $\begin{array}{l}\mathrm{R} \\
\mathrm{R} \\
\mathrm{R} \\
\mathrm{R} \\
\mathrm{R} \\
\mathrm{R}\end{array}$ & $\begin{array}{ll}\mathrm{R} & \\
\mathrm{R} & \mathrm{R} \\
& \\
\mathrm{R} & \mathrm{R} \\
\mathrm{R} & \end{array}$ & $\begin{array}{l}\mathrm{R} \\
\mathrm{R} \\
\mathrm{R} \\
\mathrm{R}\end{array}$ & R & $\begin{array}{ll} & \\
& \\
R & \\
R & F \\
R & F \\
& F \\
& F \\
& F\end{array}$ & \begin{tabular}{l|l}
$\mathrm{R}$ & \\
$\mathrm{R}$ & \\
$\mathrm{R}$ & \\
$\mathrm{R}$ & $\mathrm{R}$ \\
$\mathrm{R}$ & $\mathrm{R}$ \\
$\mathrm{r}$ & $\mathrm{R}$ \\
$\mathrm{r}$ & $\mathrm{R}$
\end{tabular} & 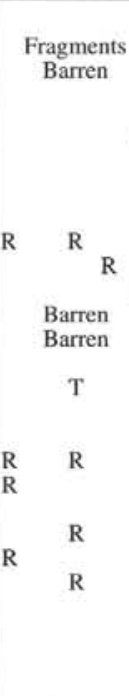 & $\mathrm{R}$ & $\begin{array}{l}\mathrm{T} \\
\mathrm{R}\end{array}$ & $\begin{array}{l}\mathrm{R} \\
\mathrm{R}\end{array}$ & $\begin{array}{l}\mathrm{R} \\
\mathrm{R} \\
\mathrm{R} \\
\mathrm{R} \\
\mathrm{R}\end{array}$ & & 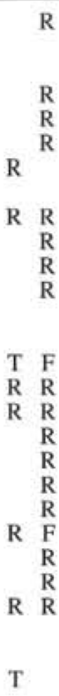 & $\begin{array}{l}\mathrm{F} \\
\mathrm{R} \\
\mathrm{R} \\
\mathrm{R} \\
\mathrm{R} \\
\mathrm{T} \\
\mathrm{T} \\
\mathrm{R} \\
\mathrm{F} \\
\mathrm{R} \\
\mathrm{R} \\
\mathrm{R}\end{array}$ & $\begin{array}{l}\mathrm{R} \\
\mathrm{R} \\
\mathrm{R}\end{array}$ & $\begin{array}{l}{ }_{R}^{R} \\
\quad R\end{array}$ & $\begin{array}{l}F \\
R \\
F \\
R \\
F \\
F \\
R \\
F \\
R \\
F \\
R \\
R \\
R \\
R\end{array}$ & $\begin{array}{c}\text { Undesignated } \\
\text { assemblage }\end{array}$ & \\
\hline $\begin{array}{l}34 X-2,57-59 \\
34 X-3,57-59 \\
34 X-4,57-59\end{array}$ & $\begin{array}{l}314.57 \\
316.07 \\
317.57\end{array}$ & $\begin{array}{l}40 \\
40 \\
40\end{array}$ & $\begin{array}{lll}\text { A } & 1 \\
\text { A } & 1 \\
\text { C } & \end{array}$ & $\begin{array}{rl}144 & 1 \\
101 & 1 \\
48 & \mathrm{~F}\end{array}$ & \begin{tabular}{l|l} 
MP & 1 \\
MP & PM
\end{tabular} & $\begin{array}{l}\mathrm{F} \\
\mathrm{R}\end{array}$ & $\begin{array}{l}\mathrm{F} \\
\mathrm{F} \\
\mathrm{F}\end{array}$ & $\begin{array}{l}R \\
R \\
R\end{array}$ & R & $\begin{array}{l}R \\
T\end{array}$ & $\begin{array}{l}\mathrm{R} \\
\mathrm{R}\end{array}$ & & $\begin{array}{l}\mathrm{T} \\
\mathrm{R}\end{array}$ & & $\begin{array}{lll}\mathrm{F} & \mathrm{F} \\
\mathrm{F} & \mathrm{I} \\
\mathrm{R} & \mathrm{F}\end{array}$ & $\begin{array}{ll}\mathrm{R} & \\
\mathrm{F} & \mathrm{R} \\
\mathrm{R} & \mathrm{R}\end{array}$ & $\begin{array}{l}\mathrm{R}_{\mathrm{T}} \\
\mathrm{T}_{\mathrm{R}}\end{array}$ & $\mathrm{R}$ & $T^{R}$ & & & $\mathrm{R}$ & $R$ & & $\begin{array}{l}\mathrm{F} \\
\mathrm{R} \\
\mathrm{R}\end{array}$ & $\begin{array}{ll}\mathrm{F} & \mathrm{T} \\
\mathrm{F} & \mathrm{T} \\
\mathrm{T} & \end{array}$ & $\begin{array}{ll} & R \\
R & R \\
& R\end{array}$ & $\begin{array}{ll}\mathrm{R} & \mathrm{C} \\
\mathrm{R} & \mathrm{T} \\
\mathrm{R} & \mathrm{R}\end{array}$ & $\begin{array}{ll}C & T \\
T & T \\
R & R\end{array}$ & \begin{tabular}{l|l}
$\mathrm{C}$ & 1 \\
$\mathrm{C}$ & \\
$\mathrm{R}$ &
\end{tabular} & $\begin{array}{l}\mathrm{R}_{\mathrm{R}} \\
\mathrm{R} \\
{ }^{\mathrm{R}}\end{array}$ & $\begin{array}{l}\mathrm{C} \\
\mathrm{C} \\
\mathrm{F}\end{array}$ & $\begin{array}{c}\text { Hermesinum } \\
\text { acus } \\
\text { Assemblage }\end{array}$ & \\
\hline $\begin{array}{l}34 X-5,9-11 \\
35 X-1,30-31 \\
35 X-2,9-10 \\
35 X-3,9-10 \\
35 X-4,9-10\end{array}$ & $\begin{array}{l}318.60 \\
320.51 \\
321.80 \\
323.30 \\
324.80\end{array}$ & \begin{tabular}{l|}
21 \\
21 \\
21 \\
21 \\
21
\end{tabular} & $\begin{array}{l}\mathrm{R} \\
\mathrm{T} \\
\mathrm{F} \\
\mathrm{R} \\
\mathrm{R}\end{array}$ & $\begin{array}{r}121 \\
2 \\
26 \\
5 \\
12\end{array}$ & $\begin{array}{c}\mathrm{PM} \\
\mathrm{P} \\
\mathrm{P} \\
\mathrm{P} \\
\mathrm{P}\end{array}$ & & $\begin{array}{l}\mathrm{F} \\
\mathrm{R}\end{array}$ & $\mathrm{R}$ & & & & $\mathbf{R}$ & & R F & $\begin{array}{ll}R \\
R\end{array}$ & R & & & & & $\mathrm{R}$ & & & & R & & & $\begin{array}{l}\mathrm{R} \\
\mathrm{R} \\
\mathrm{R}\end{array}$ & $\mathrm{R}$ & R & & $\begin{array}{l}\mathrm{R} \\
\mathrm{R} \\
\mathrm{F} \\
\mathrm{R} \\
\mathrm{R}\end{array}$ & $\begin{array}{c}\text { Undesignated } \\
\text { assemblage }\end{array}$ & $\begin{array}{l}\text { Unzoned } \\
\text { interval }\end{array}$ \\
\hline $\begin{array}{l}35 X-5,9-10, \text { to } \\
37 X-2,57-58\end{array}$ & $\begin{array}{l}326.30 \\
342.07\end{array}$ & $\begin{array}{r}21 \\
5\end{array}$ & $\begin{array}{l}\mathrm{T} \\
\mathrm{T}\end{array}$ & $\begin{array}{l}0 \\
0\end{array}$ & & & & & $\begin{array}{l}\text { arren } \\
\text { arren }\end{array}$ & & & & & & & & & & & & & $\begin{array}{l}\text { Barren } \\
\text { Barren }\end{array}$ & & & & & & & & & & & Barren & Barren \\
\hline
\end{tabular}


Table 4. Hole 913B, stratigraphic distribution of silicoflagellates in middle Eocene to lower Oligocene and middle Miocene sediments.

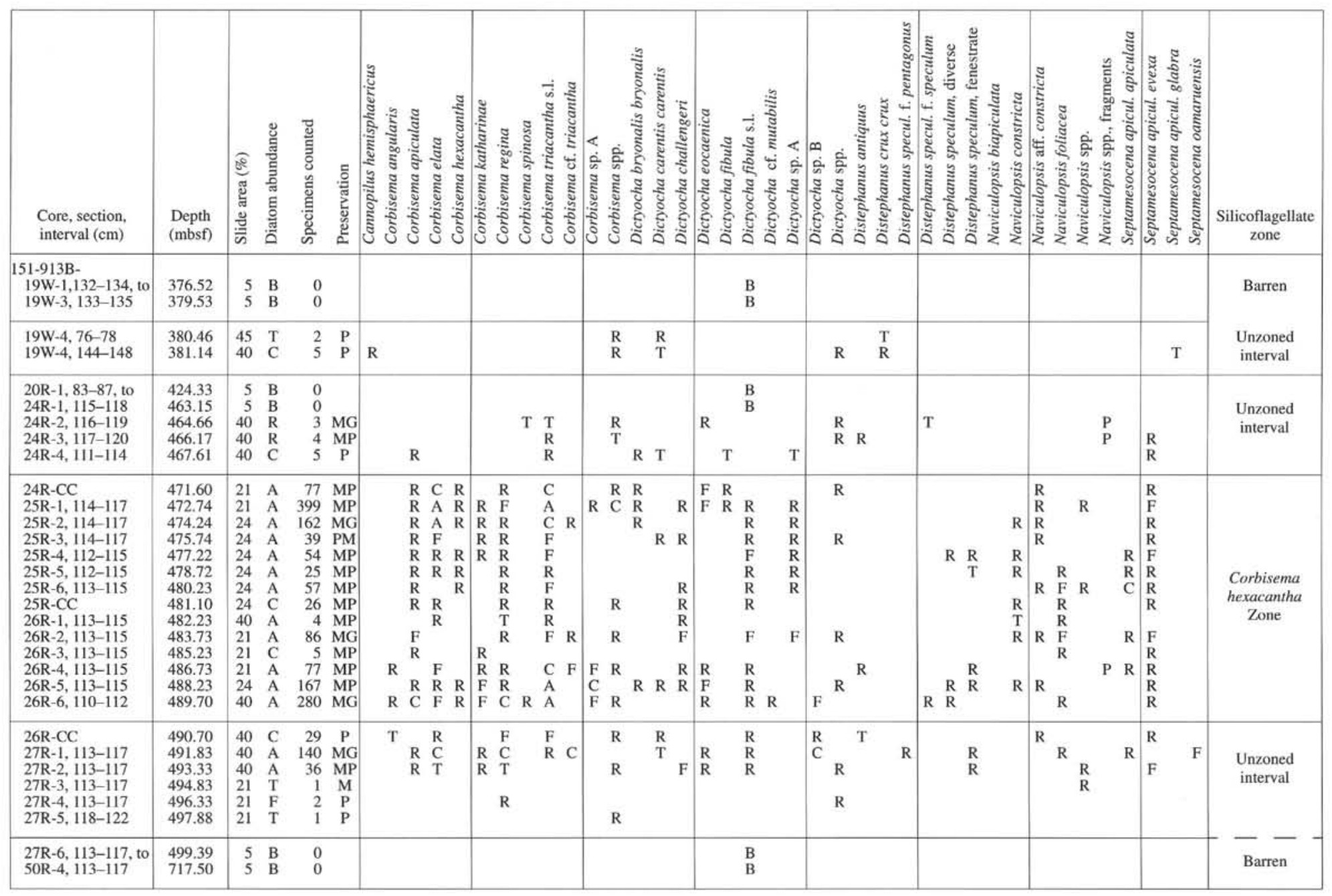

Note: For definition of species abundance and preservation, see text. 
Table 5. Hole 913B, stratigraphic distribution of ebridians and actiniscidians in middle Eocene to lower Oligocene and middle Miocene sediments.

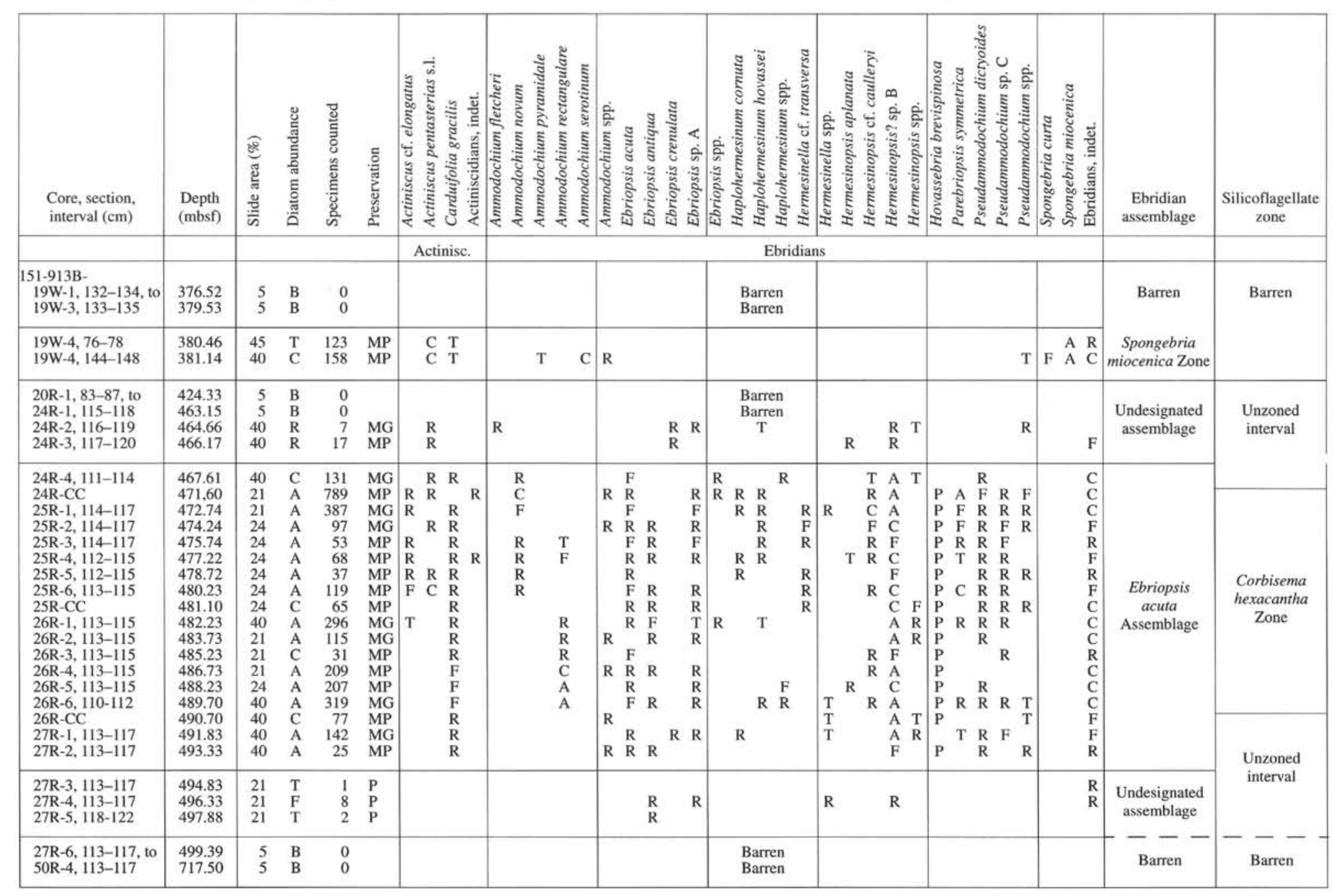

Note: For definition of species abundance and preservation, see text. 
FO of M. diodon is indicated in Chron C5ADr of Hole 642C, Norwegian Sea (Locker and Martini, 1989; Bleil, 1989), which correlates to upper Zone NN5. The age can be given as $14.7 \mathrm{Ma}$ (recalculated from Locker and Martini, 1989).

\section{FO/LO of Distephanus stauracanthus}

The FO and LO of D. stauracanthus are used to define the Distephanus stauracanthus Subzone in Atlantic and Pacific Ocean holes. In Locker and Martini (1989), both events were placed in Zone NN6, but some indications are given also for Zone NN7. In Hole 408 (Bukry, 1979), North Atlantic, the FO and LO of D. stauracanthus are possibly in Zones CN5b/6 = Zones NN7/8. In DSDP Hole 555 (Bukry, 1985a), North Atlantic, both events are indicated for Zones NN7/8 (Backman, 1984). In Hole 470 (Bukry, 1981a), Northeast Pacific, the LO may be in Zone CN5b = Zone NN7. Since the nannoplankton evidence is rather indistinct for this interval, both events are further placed into Zone NN6, comparable to many Atlantic and Pacific holes. Based on these results, the LO of D. stauracanthus may be approximately correlated to the top of Zone NN6, corresponding to an age of 13.2 Ma (Wei and Peleo-Alampay, 1993).

\section{LO of Corbisema triacantha}

The LO of C. triacantha delimits the upper Corbisema triacantha Zone. Since $C$. triacantha represents a warm-adapted species, the LO may have occurred earlier in higher latitudes than in lower ones. Sometimes sub-top occurrences of $D$. stauracanthus or supra-top occurrences of $C$. hemisphaericus or Cannopilus depressus roughly indicate the top of this zone. Nevertheless, increasing evidence indicates that the LO of C. triacantha is in Zone NN7. This applies for Holes 408 (Bukry, 1979) and 555 (Bukry 1985a) of the northern Atlantic, where Zones CN5b/6 = Zones NN7/8 are found. This proves right also for Holes 173 (Ling, 1977) and 469 (Bukry, 1981a) in the northeastern Pacific, where foraminifer cross correlation and direct nannoplankton evidence indicate Zone $\mathrm{CN} 5 \mathrm{~b}=$ Zone NN7. According to these interpretations, the LO of C. triacantha is indicated here in the middle of Zone NN7, corresponding to an age of 12.2 Ma (Wei and Peleo-Alampay, 1993).

\section{LO of Paramesocena circulus apiculata to LO of Mesocena quadrangula}

The events of Paramesocena circulus apiculata, Mesocena diodon, Distephanus aculeatus, Distephanus speculum f. octonarius and Mesocena quadrangula are well defined in Holes $642 \mathrm{C}$ and 644A of the Norwegian Sea (Locker and Martini, 1989). Using Wei and Peleo-Alampay (1993) as a source, only the ages were recalculated (Table 1).

\section{SITE SUMMARIES}

\section{Site 908}

Hole $908 \mathrm{~A}\left(78^{\circ} 23.112 \mathrm{~N}, 1^{\circ} 21.637 \mathrm{E}, 1284.5 \mathrm{~m}\right.$ of water depth) was drilled on the Hovgård Ridge which delimits the Boreas Basin to the north. The site was positioned on top of Hovgård Ridge to investigate the tectonic, sedimentological, and paleoceanographic history of this topographic element in the middle of the Fram Strait (Myhre, Thiede, Firth, et al., 1995). The sedimentary sequence recovered was divided into two lithological units. Lithologic Unit I (0-185 mbsf, Quaternary to Pliocene) consists of interbedded clayey or silty muds, clayey silts, and silty clays. Lithologic Unit II (185-345 mbsf, Oligocene) comprises predominantly biosilica-bearing silty clays. Most of the samples studied from Cores 151-908A-17X to $35 \mathrm{X}$ contain poorly to moderately preserved siliceous microfossils, such as dia- toms, silicoflagellates, ebridians, actiniscidians, chrysophyceans, radiolarians, and sponge spicules.

\section{Silicoflagellates (Table 2)}

Samples 151-908A-13X-1, 78-82 cm, through 16X-4, 48-53 cm, are barren of silicoflagellates. The interval from Sample 151-908A$17 \mathrm{X}-1,52-54 \mathrm{~cm}$, to $20 \mathrm{X}-6,57-60 \mathrm{~cm}$, displays poorly preserved assemblages which are probably all reworked from older, mainly $\mathrm{Pa}-$ leogene, strata. Strong reworking is indicated especially by Lyramula furcula, which occurs only in upper Cretaceous sediments. No age diagnostic silicoflagellates could be found for that interval.

The sequence from Sample 151-908A-21X-1, 56-57 cm, to $35 \mathrm{X}-$ $4,9-10 \mathrm{~cm}$, is characterized by changing preservational conditions. Intervals that have moderately preserved assemblages clearly alternate with intervals that have poorly preserved assemblages. The bulk of species obviously occurs throughout the column without major differentiation. But some species within intervals of better preservation hint at an influence of North Atlantic surface-water. Such species are Cannopilus hemisphaericus, Distephanus crux, D. paulii, D. speculum, Septamesocena apiculata subsp. glabra, and some Naviculopsis taxa.

The co-occurrence of $C$. hemisphaericus and $C$. jouseae indicates that the entire sequence from Sample 151-908A-21X-1, 56-57 cm, to $34 \mathrm{X}-3,57-59 \mathrm{~cm}$, belongs in the Cannopilus hemisphaericus Zone, which is of late Oligocene age. The restricted occurrence of $D$. paulii marks a distinct interval or subzone within this zone. Assuming the FO of Cannopilus hemisphaericus is in the middle of nannoplankton Zone NP24 (Fig. 2), Chron C9r may be present below $320 \mathrm{~m}$.

The interval from Sample 151-908A-34X-4, 57-59 cm, to $35 \mathrm{X}-4$, 9-10 cm, remains unzoned, because diagnostic silicoflagellates are missing. Samples 151-908A-35X-5, 9-10 cm, through 37X-2, 57-58 $\mathrm{cm}$, are barren of silicoflagellates.

\section{Ebridians and Actiniscidians (Table 3)}

Samples 151-908A-13X-1, 78-82 cm, through $16 \mathrm{X}-4,48-53 \mathrm{~cm}$, are barren of ebridians and other siliceous flagellates. The interval from Sample 151-908A-17X-1, 52-54 cm, to 20X-6, 57-60 cm, contains a limited number of species which are mainly reworked from Paleogene strata. A single specimen of Thranium sp. found in Sample $151-908 \mathrm{~A}-18 \mathrm{X}-1,58-60 \mathrm{~cm}$, is probably autochthonous. It hints at a time interval from the middle Miocene to the earliest Pliocene (see Locker and Martini, 1989). Hence, the paleomagnetic sequence above the hiatus at about $186 \mathrm{~m}$ (Myhre, Thiede, Firth, et al., 1995) may represent Chron $\mathrm{C} 3$ or $\mathrm{C} 3 \mathrm{~A}$.

The sequence from Sample 151-908A-21X-1, 56-57 cm, to $35 \mathrm{X}$ $4,9-10 \mathrm{~cm}$, is characterized by several ebridian and actiniscidian species, such as Carduifolia gracilis, Ebriopsis crenulata, Hermesinopsis exigua, and other taxa. A distinct interval is indicated by Hermesinella paraconata, which ranges from Sample 151-908A-21X-5, $56-57 \mathrm{~cm}$, to $24 \mathrm{X}-2,58-59 \mathrm{~cm}$. Two short intervals, covering Samples 151-908A-28X-5, 57-59 cm, and 28X-6, 57-59 cm, and Samples $151-908 \mathrm{~A}-34 \mathrm{X}-2,57-59 \mathrm{~cm}$, to $34 \mathrm{X}-4,57-59 \mathrm{~cm}$, are characterized by Hermesinum acus. The entire sequence correlates with the Cannopilus hemisphaericus Zone of silicoflagellates, which is of late Oligocene age.

Samples 151-908A-35X-5, 9-10 cm, through $37 X-2,57-58 \mathrm{~cm}$, from the basal part of the hole are barren of ebridians and other siliceous flagellates.

\section{Site 913}

Hole $913 \mathrm{~B}\left(75^{\circ} 29.356^{\prime} \mathrm{N}, 06^{\circ} 56.810^{\prime} \mathrm{W}, 3318.4 \mathrm{~m}\right.$ of water depth) was drilled in the deep Greenland Basin on oceanic crust slightly older than Anomaly 24B. The site was planned as the north- 
ernmost end-member of a transect along the East Greenland margin to investigate the evolution of the East Greenland Current, the formation of deep-water in the Greenland Basin, and the onset of Northern Hemisphere glaciation (Myhre, Thiede, Firth, et al., 1995). The sedimentary sequence recovered was divided into three lithological units. Lithologic Unit I ( $0-3$ mbsf, Quaternary) consists of interbedded clays, silts, sands, and biocarbonate-bearing clays. Lithologic Unit II (3-388 mbsf, Quaternary to Miocene) comprises interbedded clayey to silty muds, silty clays, and clayey silts. Lithologic Unit III (388-770 mbsf, Miocene to Eocene) consists of interbedded massive and laminated silty clays, various biosilica-bearing clayey sediments, laminated clays, and silty clays and muds. Samples studied from Cores 151-913B-19W to 50R revealed that siliceous microfossils are present only in certain intervals, especially in Core 151-913B-19W and Cores 151-913B-24R to 27R. The microfossil assemblages comprise poorly to moderately preserved diatoms, silicoflagellates, ebridians, actiniscidians, chrysophyceans, radiolarians, and sponge spicules.

\section{Silicoflagellates (Table 4)}

Samples 151-913B-19W-1, 132-134 cm, through 19W-3, 133$135 \mathrm{~cm}$, are barren of silicoflagellates. Samples 151-913B-19W-4, 76-78 cm, and 19W-4, 144-148 cm, contain rare specimens of Cannopilus hemisphaericus and Distephanus crux, which suggests an interval above the FAD of $C$. hemisphaericus in Oligocene time (Fig. 2).

The interval from Sample 151-913B-20R-1, 83-87 cm, to $24 \mathrm{R}$ $1,115-118 \mathrm{~cm}$, is barren of silicoflagellates. Most peculiar is the occurrence of many radiolarian fragments in Sample 151-913B-24R-1, $115-118 \mathrm{~cm}$, which suggests a horizon of strong reworking.

Samples $151-913 \mathrm{~B}-24 \mathrm{R}-2,116-119 \mathrm{~cm}$, to $24 \mathrm{R}-4,111-114 \mathrm{~cm}$, contain a few nondiagnostic silicoflagellate skeletons. The sequence from Sample 151-913B-24R-CC to 26R-6, 110-112 cm, displays highly diversified assemblages comprising Corbisema hexacantha, C. regina, Dictyocha challengeri, Naviculopsis foliacea, and other species. The consistent occurrence of $C$. hexacantha in these samples indicates the Corbisema hexacantha Zone of middle to late Eocene age (Fig. 2).

The interval from Sample 151-913B-26R-CC to 27R-5, 118-122 $\mathrm{cm}$, remains unzoned, because diagnostic silicoflagellates are missing. Samples 151-913B-27R-6, 113-117 cm, through 50R-4, 113$117 \mathrm{~cm}$, are barren of silicoflagellates.

\section{Ebridians and Actiniscidians (Table 5)}

Samples 151-913B-19W-1, 132-134 cm, through 19W-3, 133$135 \mathrm{~cm}$, are barren of ebridians and other siliceous flagellates. Samples 151-913B-19W-4, 76-78 cm, and 19W-4, 144-148 cm, are dominated by Spongebria miocenica and Actiniscus pentasterias. According to the results of analysis of Hole $642 \mathrm{C}$, the occurrence of Spongebria miocenica clearly points at a middle Miocene interval around Chron C5B, corresponding to upper Zone NN4 and Zone NN5 (Locker and Martini, 1989).

The sequence from Sample 151-913B-20R-1, 83-87 cm, to 24R$1,115-118 \mathrm{~cm}$, is barren both of ebridians and other siliceous flagellates. Samples 151-913B-24R-2, 116-119 cm, and 24R-3, 117-120 $\mathrm{cm}$, contain only rare specimens of ebridians and actiniscidians. However, from Sample 151-913B-24R-4, 111-114 cm, to 27R-2, $113-117 \mathrm{~cm}$, highly diversified assemblages follow. Most common are specimens of Hermesinopsis sp. B. The entire interval can be characterized by the joint occurrence of three Ebriopsis species, under which Ebriopsis acuta dominates. The whole sequence correlates, more or less, with the Corbisema hexacantha Zone of silicoflagellates, which is of middle to late Eocene age.

The interval from Sample 151-913B-27R-3,113-117 cm, to $27 \mathrm{R}$ $5,118-122 \mathrm{~cm}$, contains only a few undiagnostic ebridians. Samples
151-913B-27R-6, 113-117 cm, through 50R-4, 113-117 cm, are barren of ebridians and other siliceous flagellates.

\section{PALEOCEANOGRAPHIC IMPLICATIONS}

Although DSDP Leg 38 and ODP Leg 104 yielded Paleogene sediments from the Norwegian-Greenland Sea, our knowledge of the early history of this ocean is still very limited. As long as sediment sequences and respective time equivalents are delivered in short fragments, the history can be reconstructed only piece by piece. However, high-resolution studies of sediment sequences recovered during ODP Leg 151 will help to decifer the Paleogene evolution of the Norwegian-Greenland Sea.

Silicoflagellate species are important indicators for paleoenvironmental changes during the past. Special ecological adaptations of species may explain the distribution of warm and cold surface-water masses. Certain species found at different localities may indicate connections between widely separated oceanic regions, either via broad shelf areas or via oceanic gateways.

During the late Cretaceous, the Norwegian-Greenland Sea was probably a shallow and narrow seaway (Ziegler, 1982) with some surface-water exchange to the Arctic Ocean, as indicated by the reworked upper Cretaceous silicoflagellate Lyramula furcula found in Miocene-Pliocene sediments of Hole 908A. In the Late Cretaceous, the Arctic Ocean was a high-productivity area that produced high amounts of siliceous plankton, including various silicoflagellate species (see Ling et al., 1973; Bukry, 1981c, 1985b).

The history of the Norwegian-Greenland Sea as a deep ocean started when rifting and drifting commenced in the early Eocene at about $54.7 \mathrm{Ma}$ (Eldholm et al., 1989). From the early middle Eocene, only silicoflagellate assemblages containing Naviculopsis minor and Corbisema spinosa are known from DSDP Hole 343 (Martini and Müller, 1976), which may be endemic. During late middle and late Eocene, the Norwegian-Greenland Sea was probably well connected to the Arctic Ocean and adjoining regions, as can be deduced from similar silicoflagellate assemblages. Both in Arctic Core Fl-422 (Bukry, 1984) and in Norwegian-Greenland Sea Holes 340 (Martini and Müller, 1976) and 913B, middle to late Eocene silicoflagellate assemblages containing Corbisema spinosa and Corbisema hexacantha were found.

Some ebridian species provide additional data for paleoceanographic comparisons. The occurrence of Ammodochium fletcheri in Hole 913B appears most remarkable, because it was first recorded from Core Fl-422 of the Arctic Ocean (Ling, 1985), which is correlated to the middle to upper Eocene Corbisema hexacantha Zone (Bukry, 1984). Parebriopsis symmetrica, first described from the upper Eocene to lower Oligocene of Vema Site 43 on the Vøring Plateau (Perch-Nielsen, 1978), was also found in the Eocene sequence of Hole $913 \mathrm{~B}$ on the East Greenland margin.

The time interval from the late Eocene to the early Oligocene is insufficiently known, although respective sediments have been described from DSDP Holes 338 and 339 (Martini and Müller, 1976). The late Oligocene interval, however, is now well documented by sediments from Hole 908A that contain silicoflagellate assemblages with Cannopilus hemisphaericus and Cannopilus jouseae. In this context, a special aspect of these assemblages must be discussed.

The late Oligocene assemblages recovered at Site 908 show several fluctuations in their composition. Well preserved assemblages include, beside a host of other species, Cannopilus hemisphaericus, Dictyocha bryonalis, Distephanus crux, D. paulii, D. speculum, and Septamesocena apiculata subsp. glabra (Table 2). Owing to the general habitus of skeletons, these assemblages probably indicate a restricted influence of surface-water from the North Atlantic. This is confirmed by upper Oligocene assemblages found at Silstrup in Denmark that solely include Cannopilus hemisphaericus, Distephanus crux, Distephanus speculum, and Septamesocena apiculata subsp. 
glabra (von Salis, 1993). In contrast, less well-preserved assemblages do not exhibit those species, but they contain Corbisema lammellifera, Dictyocha carentis, D. deflandrei, D. rotundata, and Distephanus antiquus. This may be explained either by changing preservational conditions or by changing paleoceanographic connections. Since many species of the latter assemblages were thoroughly described from the West Siberian Platform and the Ural Strait (Glezer, 1970), paleoceanographic connections via the Arctic Ocean or the Barents Sea may be indicated.

Some ebridian species contribute additional paleoceanographic data. Hermesinum geminum, which is continously present in the deeper part of Hole 908A, was first described from the upper Eocene and the Oligocene of DSDP Hole 280 and from the upper Oligocene of DSDP Hole 278 in the southwestern Pacific (Perch-Nielsen, 1975). It was also indicated for the upper Eocene of the Vøring Plateau in the Norwegian Sea (Perch-Nielsen, 1975, 1978). Ammodochium pyramidale, which is present throughout the upper Oligocene of Hole 908A, reaches into the lower and middle Miocene of Hole 642C in the Norwegian Sea (Locker and Martini, 1989).

The assemblages of siliceous flagellates demonstrate that a permanent surface-water exchange may have existed between the Norwegian-Greenland Sea, the Arctic Ocean, and probably also the Barents Sea during Eocene and Oligocene times. Minor surface-water input from the North Atlantic is indicated by certain silicoflagellate species for the late Oligocene.

\section{TAXONOMY}

Taxonomic data of silicoflagellates, ebridians, and other siliceous flagellates are presented in an alphabetical list of species, subspecies, and forms. The data were summarized from Loeblich et al. (1968), from Locker (1974), and from DSDP/ODP publications. All taxa were treated as outlined in Locker and Martini (1986).

More than 15 taxa of silicoflagellates and ebridians were recognized as new, but most of them will be described elsewhere. Only three ebridian species that characterize middle to upper Eocene and upper Oligocene assemblages are introduced here as new. They are described according to the requirements of the International Code of Botanical Nomenclature (Greuter, 1994). The holotypes are deposited in the Senckenberg Museum, Frankfurt/ Main, Germany.

\section{Silicoflagellates}

Genus: Cannopilus Haeckel, 1887

Cannopilus hemisphaericus (Ehrenberg, 1845) Haeckel, 1887: Plate 1, fig. 2. Cannopilus cf. hemisphaericus (Ehrenberg, 1845) Haeckel, 1887: Not figured.

Cannopilus jouseae Bachmann in Ichikawa et al., 1964: Plate 1, fig. 3.

Genus: Corbisema Hanna, 1928

Corbisema angularis Bukry, 1984: Not figured.

Corbisema apiculata (Lemmermann, 1901) Hanna, 1931: Plate 1, fig. 13. Corbisema archangelskiana (Schulz, 1928) Frenguelli, 1940: Plate 4, fig. 5. Corbisema convexa (Bukry, 1978) Locker and Martini, 1986: Plate 1, fig. 4. Corbisema elata (Glezer, 1962) Locker and Martini, 1987: Plate 1, fig. 7. Corbisema glezerae Bukry, 1976: Plate 1, fig. 8.

Corbisema globulata (Bukry, 1976) Locker and Martini, 1987: Plate 1, fig. 9. Corbisema hastata (Lemmermann, 1901) Frenguelli, 1940: Not figured. Corbisema hexacantha (Schulz, 1928) Deflandre, 1950: Plate 1, fig. 6. Corbisema katharinae Bukry, 1976: Plate 1, fig. 15.

Corbisema lamellifera subsp. constricta (Glezer, 1964): Not figured. Corbisema lamellifera subsp. hastata (Glezer, 1964): Not figured.

Corbisema lamellifera (Glezer, 1962) subsp. lamellifera: Plate 1, fig. 14. Corbisema reducta (Glezer, 1964) n. comb.: Plate 1, fig. 10.

Basionym: Dictyocha elata var. media f. reducta Glezer, 1964; p. 51, pl. 1 , fig. 8.

Corbisema regina Bukry, 1984: Plate 1, fig. 11.

Corbisema spinosa Deflandre, 1950: Plate 1, fig. 5.

Corbisema toxeuma Bukry, 1978: Not figured.

Corbisema triacantha s.I. (Ehrenberg, 1845) Hanna, 1931: Plate 1, fig. 12.

Corbisema cf, triacantha (Ehrenberg, 1845) Hanna, 1931: Not figured.
Corbisema sp. A: Plate 1, fig. 16.

Description: Basal ring constructed of basal bars which are strongly curved to the outside. Basal bars without basal pikes. Apical structure consisting of three bars which arise moderately and meet in the center.

Corbisema spp.

Remarks: This category includes rare occurences of $C$. glezerae, $C$. regi$n a$, and C. toxeuma in Hole 908A, and of C. convexa, C. globulata, C. lamellifera, and C. reducta in Hole 913B.

\section{Genus: Dictyocha Ehrenberg, 1840}

Dictyocha bryonalis Bukry, 1984 subsp. bryonalis: Plate 2, fig. 5.

Dictyocha bryonalis subsp. A: Plate 2, fig. 6.

Description: Basal ring rhomboidal and with distinctly inflected basal bars. Basal bars often without basal pikes. Apical structure consisting of a short apical bar and four struts. Apical bar aligned with the short axis and twisted anticlockwise.

Dictyocha carentis (Glezer, 1964) subsp. carentis n. comb.: Plate 2, fig. 1.

Basionym: Dictyocha frenguellii var. carentis Glezer, 1964; p. 52, pl. 1 , figs. 12-16.

Dictyocha carentis subsp. incerta (Glezer, 1964) n. comb.: Plate 2, fig. 2.

Basionym: Dictyocha frenguellii var. carentis f. incerta Glezer, 1964; p. 52 , pl. 1, figs. 15-16.

Dictyocha challengeri Martini and Müller, 1976: Plate 4, fig. 4.

Dictyocha deflandrei Frenguelli ex Glezer, 1966: Plate 2, fig. 3.

Dictyocha eocaenica (Krotov ex Glezer, 1960) Martini, 1981: Plate 4, fig. 7.

Dictyocha fibula Ehrenberg, 1840: Not figured.

Dictyocha fibula s.l. Ehrenberg, 1840: Not figured.

Dictyocha frenguellii Deflandre, 1950: Plate 2, fig. 7.

Dictyocha martinii (Bukry, 1975) n. comb.: Not figured.

Basionym: Dictyocha aspera subsp. martinii Bukry, 1975; p. 854, pl. 2, figs. 5-8.

Dictyocha cf. mutabilis Deflandre, 1950: Not figured.

Dictyocha obliqua Glezer, 1964: Plate 2, fig. 10.

Dictyocha precarentis Bukry, 1976: Plate 2, fig. 8.

Dictyocha rotundata Jouse, 1955 subsp. rotundata: Plate 2, fig. 4 .

Dictyocha rotundata subsp. secta (Glezer, 1962) n. comb.: Not figured.

Basionym: Dictyocha rotundata var. secta Glezer, 1962; p. 152, figs. 5zk.

Dictyocha transitoria Deflandre, 1932: Plate 2, fig. 9.

Dictyocha sp. A: Plate 3, fig. 11.

Description: Basal ring elongated rhomboidal and with straight basal bars. Basal bars relatively thick and with basal pikes. Apical structure consisting of an apical bar and four struts. Apical bar aligned with the long axis and strikingly thin.

Dictyocha sp. B: Plate 4, fig. 6.

Description: Basal ring elongated ovoidal. Basal bars without basal pikes. Apical structure consisting of a short apical bar and four struts. Apical bar aligned with the short axis. Radial spines only along the long axis of the basal ring.

Dictyocha spp.

Remarks: This category includes rare occurrences of $D$. eocaenica in Hole $908 \mathrm{~A}$, and of $D$. precarentis, D. rotundata, and $D$. transitoria in Hole 913B.

Genus: Distephanus Stöhr, 1880

Distephanus antiquus Glezer, 1964: Plate 2, fig. 11.

Distephanus crux (Ehrenberg, 1841) Haeckel, 1887 subsp. crux: Plate 3, fig. 1.

Distephanus crux subsp. A: Plate 3, fig. 2.

Description: Basal ring rhomboidal composed of irregularly inflected basal bars. Basal bars with basal pikes. Apical structure consisting of a large apical ring and four struts. Radial spines relatively long.

Distephanus norvegiensis Perch-Nielsen, 1976: Plate 2, fig. 12.

Distephanus paulii (Shaw and Ciesielski, 1983) n. comb.: Plate 3, fig. 3.

Basionym: Distephanus crux subsp. paulii Shaw and Ciesielski, 1983; p. 713 , pl. 11, figs. $2-3,5-6$.

Distephanus speculum $\mathrm{f}$. pentagonus (Lemmermann, 1901) Locker and Martini, 1986: Plate 2, fig. 13.

Distephanus speculum f. schulzii n. nom.: Plate 2, fig. 14.

Remarks: This form is regarded as a variant of Distephanus speculum. Since Distephanus speculum var. pentagonus Lemmermann, 1901 is preoccupied by forms with an apical ring, for the taxon Dictyocha fib- 
ula var. pentagona Schulz, 1928 the new name Distephanus speculum f. schulzii is proposed.

Basionym: Dictyocha fibula var. pentagona Schulz, 1928; p. 255, figs. $41 \mathrm{a}-\mathrm{b}$.

Distephanus speculum f. septenarius (Ehrenberg, 1845) Locker and Martini, 1986: Plate 2, fig. 16.

Distephanus speculum (Ehrenberg, 1840) Haeckel, 1887 f. speculum: Plate 2. fig. 15.

Distephanus speculum (Ehrenberg, 1840), diverse forms

Distephanus speculum (Ehrenberg, 1840) fenestrate forms

Genus: Lyramula Hanna, 1928

Lyramula furcula Hanna, 1928: Plate 1, fig. 1.

Genus: Mesocena Ehrenberg, 1841

Mesocena quadrangula Ehrenberg ex Haeckel, 1887: Plate 3, fig. 12.

Genus: Naviculopsis Frenguelli, 1940

Naviculopsis aspera (Schulz, 1928) Perch-Nielsen, 1976: Plate 3, fig. 5. Naviculopsis biapiculata (Lemmermann, 1901) Frenguelli, 1940: Plate 3, fig. 6.

Naviculopsis constricta (Schulz, 1928) Frenguelli, 1940: Plate 3, fig. 10. Naviculopsis aff. constricta (Schulz, 1928) Frenguelli, 1940: Plate 3, fig. 7. Naviculopsis danica Perch-Nielsen, 1976: Plate 3, fig. 13.

Naviculopsis eobiapiculata Bukry, 1978: Plate 3, fig. 9.

Naviculopsis foliacea Deflandre, 1950: Plate 3, fig. 8.

Naviculopsis minor (Schulz, 1928) Frenguelli, 1940: Plate 3, fig. 4.

Naviculopsis punctilia Perch-Nielsen, 1976: Not figured.

Naviculopsis spp.

Remarks: This category includes rare occurrences of $N$. danica, $N$. foliacea, and N. punctilia in Hole 908A, and of N. minor in Hole 913B.

Genus: Septamesocena Bachmann, 1970

Septamesocena apiculata (Schulz, 1928) Bachmann, 1970 subsp. apiculata: Plate 4, fig. 2.

Septamesocena apiculata subsp. evexa Bukry, 1985: Plate 4, fig. 3.

Septamesocena apiculata subsp. glabra (Schulz, 1928) n. comb.: Plate 4, fig. 1.

Basionym: Mesocena polymorpha var. triangula f. glabra Schulz, 1928; p. 237 , figs. $3 \mathrm{~b}-\mathrm{c}$.

Septamesocena oamaruensis (Schulz, 1928) n. comb.: Not figured.

Basionym: Mesocena oamaruensis Schulz, 1928; p. 240, figs. 10a-b.

\section{Ebridians}

Genus: Ammodochium Hovasse, 1932

Ammodochium danicum Deflandre, 1951: Plate 5, fig. 1.

Ammodochium complexum Dumitrica and Perch-Nielsen, 1978: Not figured.

Ammodochium doliolum Hovasse, 1932: Plate 5, fig. 5.

Ammodochium fletcheri Ling, 1985: Plate 5, fig. 4.

Ammodochium novum Perch-Nielsen, 1978: Plate 5, fig. 13.

Ammodochium pyramidale Hovasse, 1943: Plate 5, fig. 3.

Ammodochium rectangulare (Schulz, 1928) Deflandre, 1933: Plate 5, fig. 2.

Ammodochium serotinum Locker and Martini, 1986: Plate 5, fig. 12.

Ammodochium sp. A: Plate 5, fig. 6.

Description: Barrel-like skeletons. Proclades and opisthoclades pierced by large openings. Triode in lateral view with small openings near the margin.

Ammodochium spp.

Remarks: This category includes mainly undetermined specimens, but also some occurrences of A.fletcheri in Hole 908A, and of A. complexum in Holes 908A and 913B.

Genus: Ditripodium Hovasse, 1932

Ditripodium amphora Hovasse, 1943: Not figured.

Ditripodium latum Hovasse, 1932: Plate 6, fig. 11.

Ditripodium spp.

Remarks: The few occurrences of D. amphora and D. latum in Hole $908 \mathrm{~A}$ are summarized in this category.
Genus: Ebriopsis Hovasse, 1932

Ebriopsis antiqua (Schulz, 1928) Hovasse, 1932: Plate 6, fig. 2.

Ebriopsis crenulata Hovasse, 1932: Plate 6, fig. 3.

Ebriopsis sp. A: Plate 6, fig. 5.

Description: Skeletons circular or ovoidal in outline and distinctly compressed. Clades twisted in such a manner that two pseudotriodes arise.

Ebriopsis spp.

Remarks: This category includes unidentified specimens from Hole 913B.

Genus: Falsebria Deflandre, 1951

Falsebria ambigua Deflandre, 1951: Not figured.

Falsebria rossica Deflandre, 1950: Plate 5, fig. 28.

Genus: Haplohermesinum Hovasse, 1943

Haplohermesinum cornuta (Dumitrica and Perch-Nielsen, 1975) n. comb.: Plate 5, fig. 19.

Basionym: Ebriopsis cornuta Dumitrica and Perch-Nielsen, 1975; PerchNielsen (1975), p. 880, pl. 2, figs. 8-9.

Haplohermesinum hovassei Locker and Martini, 1989: Plate 5, fig. 20.

Haplohermesinum sp. A: Plate 5, fig. 21.

Description: Skeletons basket-like. One opisthocladian opening is reduced so that the skeleton appears asymmetrical.

Genus: Hermesinella Deflandre, 1934

Hermesinella conata (Deflandre, 1951) Locker and Martini, 1986: Plate 5, fig. 14.

Hermesinella fenestrata Frenguelli, 1951: Plate 5, fig. 16.

Hermesinella schulzii (Hovasse, 1932) Locker and Martini, 1989: Plate 5, fig. 17.

Hermesinella cf. transversa Deflandre, 1934: Plate 5, fig. 18.

Hermesinella spp.

Remarks: This category includes unidentified specimens from Hole 913B.

Genus: Hermesinopsis Deflandre, 1934

Hermesinopsis aplanata (Deflandre, 1950) n. comb.: Plate 5, fig. 26.

Basionym: Ebriopsis aplanata Deflandre, 1950; p. 159, figs. 1-2.

Hermesinopsis cf. caulleryi Deflandre, 1934: Plate 5, fig. 22.

Hermesinopsis exigua (Deflandre, 1951) n. comb.: Plate 5, fig. 23.

Basionym: Ebriopsis exigua Deflandre, 1951; p. 27, 66, figs. 62-64.

Hermesinopsis valida (Deflandre, 1934) n. comb.: Plate 5, fig. 25.

Basionym: Parebria valida Deflandre, 1934; p. 91, figs. 33-36.

Hermesinopsis sp. A: Plate 6, fig. 4.

Description: Small skeletons ovoidal and with distinct indentions at the margin. Opisthocladian openings have different size.

Hermesinopsis sp. B: Plate 5, fig. 24.

Description: Small skeletons basket-like and elongated. Syncladal ring pierced by a set of small openings. Actines of the triaene often with a small opening at the margin.

Hermesinopsis spp.

Remarks: This category includes mainly unidentified specimens of Holes 908A and 913B, but also some occurrences of $H$. valida in Hole 913B.

Genus: Hermesinum Zacharias, 1906

Hermesinum geminum Dumitrica and Perch-Nielsen, 1975: Plate 6, fig. 7. Hermesinum obliquum Locker and Martini, 1986: Plate 6, fig. 6.

Genus: Hovassebria Deflandre, 1936

Hovassebria brevispinosa (Hovasse, 1932) Deflandre, 1936: Plate 5, fig. 29.

Genus: Parebriopsis Hovasse, 1932

Parebriopsis symmetrica Dumitrica and Perch-Nielsen, 1978: Plate 5, fig. 27.

Genus: Pseudammodochium Hovasse, 1932

Pseudammodochium dictyoides Hovasse, 1932: Plate 5, fig. 7. 
Pseudammodochium eximium Deflandre, 1951: Plate 5, fig. 8.

Pseudammodochium sp. A: Plate 5, fig. 10.

Description: Skeletons urn-like and somewhat elongated. Wall relatively thick and pierced by many small pores. Triode thick and without pores near the margin.

Pseudammodochium sp. B: Plate 5, fig. 11.

Description: Skeletons broadly urn-like. Wall relatively thick and pierced with a resticted number of large pores. Triode thick and with pores near the margin.

Pseudammodochium sp. C: Plate 5, fig. 9.

Description: Skeletons urn-like and strongly elongated. Wall thin and pierced by many small pores. Triode thin and without pores near the margin.

Pseudammodochium spp.

Remarks: This category includes mainly unidentified specimens of Holes $908 \mathrm{~A}$ and $913 \mathrm{~B}$.

Genus: Spongebria Deflandre, 1950

Spongebria curta Locker and Martini, 1989: Plate 6, fig. 10.

Spongebria marthae Deflandre, 1950: Plate 5, fig. 30.

Spongebria miocenica Locker and Martini, 1989: Plate 6, fig. 16.

Genus: Thranium Hovasse, 1932

Thranium sp.: Plate 6, fig. 17.

\section{Actiniscidians}

Genus: Actiniscus Ehrenberg, 1841

Actiniscus elongatus Dumitrica, 1968: Plate 6, fig. 12.

Actiniscus cf. elongatus Dumitrica, 1968: Not figured.

Actiniscus pentasterias s.1. Ehrenberg, 1841: Plate 6, fig. 15.

Genus: Carduifolia Hovasse, 1932

Carduifolia gracilis Hovasse, 1932: Plate 6, fig. 19.

Carduifolia lata Hovasse, 1932: Plate 6, fig. 13.

Carduifolia onopordoides Hovasse, 1932: Plate 6, fig. 18.

Carduifolia spp.

Remarks: This category includes unidentified specimens of Hole 908A, but also rare occurrences of $C$. lata.

Genus: Foliactiniscus Dumitrica, 1973

Foliactiniscus atlanticus Perch-Nielsen, 1978: Plate 6, fig. 14.

\section{Synuraceans}

Genus: Macrora Hanna, 1932

Macrora stella (Azpeitia, 1911) Hanna, 1932: Plate 6, fig. 20.

\section{DESCRIPTION OF NEW TAXA}

Ebriopsis acuta n. sp.

Holotype: SM.B 16144; Plate 6, Fig. 1.

Type locality: Site 913, East Greenland margin, Sample 151-913B-25R-1, $114-117 \mathrm{~cm}$, middle to upper Eocene.

Diagnosis: Skeletons drop-like in outline and distinctly compressed. Clades twisted in such a manner that two pseudotriodes arise.

Remarks: This species is clearly differentiated against other species of the genus by its drop-like outline.

Occurrence: Consistently found from Sample 151-913B-24R-4, 111-114 $\mathrm{cm}$, to $27 \mathrm{R}-2,113-117 \mathrm{~cm}$. Nominate species of the Ebriopsis acuta Assemblage, middle to upper Eocene.

\section{Hermesinella paraconata $\mathrm{n} . \mathrm{sp}$.}

Holotype: SM.B 16145; Plate 5, Fig. 15.

Type locality: Site 908, Fram Strait, Sample 151-908A-21X-6, 57-58 cm, upper Oligocene.
Diagnosis: Skeletons basket-like. One set of proclades and opisthoclades is strongly reduced to a broad tip pierced by a small opening.

Remarks: This species is differentiated against other species of the genus by one strongly reduced set of proclades and opisthoclades.

Occurrence: Found from Sample 151-908A-21X-5, 56-57 cm, to 24X-2, $58-59 \mathrm{~cm}$. Nominate species of the Hermesinella paraconata Assemblage, upper Oligocene.

\section{Hermesinum acus n. sp.}

Holotype: SM.B 16146, Plate 6, Figs. 8, 9.

Type locality: Site 908, Fram Strait, Sample 151-908A-28X-6, 57-59 cm, upper Oligocene.

Diagnosis: Skeletons needle-like. Proclades strongly reduced to a knob-like set of bars.

Remarks: There is no other species of the genus that has such a strongly reduced skeleton, like a needle in appearance.

Occurrence: Found in two distinct intervals, in Samples 151-908A-28X-5, $57-59 \mathrm{~cm}$, and $28 \mathrm{X}-6,57-59 \mathrm{~cm}$, and in Samples 151-908A-34X-2, 57$59 \mathrm{~cm}$, to $34 \mathrm{X}-4,57-59 \mathrm{~cm}$. Nominate species of the Hermesinum acus Assemblages, upper Oligocene.

\section{ACKNOWLEDGMENTS}

Thanks are due the Deutsche Forschungsgemeinschaft, Bonn, for supporting the present study. I gratefully acknowledge various discussions with D. Spiegler and T. Wolf, both of Kiel, and E. Martini, Frankfurt. Also helpful were discussions with the members of the Kiel Postcruise Meeting. I thank E. Martini, Frankfurt, K. von Salis, Zurich, and an unknown reviewer for their careful reviews.

\section{REFERENCES}

Backman, J., 1984. Cenozoic calcareous nannofossil biostratigraphy from the northeastern Atlantic Ocean-Deep Sea Drilling Project Leg 81. In Roberts, D.G., and Schnitker, D., et al., Init. Repts. DSDP, 81: Washington (U.S. Govt. Printing Office), 403-428.

Barron, J.A., Bukry, D., and Poore, R.Z., 1984. Correlation of the middle Eocene Kellogg Shale of northern California. Micropaleontology, $30: 138-170$.

Bleil, U., 1989. Magnetostratigraphy of Neogene and Quaternary sediment series from the Norwegian Sea: Ocean Drilling Program, Leg 104. In Eldholm, O., Thiede, J., Taylor, E., et al., Proc. ODP, Sci. Results, 104: College Station, TX (Ocean Drilling Program), 829-901.

Bukry, D., 1975. Silicoflagellate and coccolith stratigraphy, Deep Sea Drilling Project, Leg 29. In Kennett, J.P., Houtz, R.E., et al., Init. Repts. DSDP, 29: Washington (U.S. Govt. Printing Office), 845-872.

1978a. Cenozoic coccolith and silicoflagellate stratigraphy, offshore northwest Africa, Deep Sea Drilling Project Leg 41. In Lancelot, Y., Seibold, E., et al., Init. Repts. DSDP, 41: Washington (U.S. Govt. Printing Office), 689-707.

, 1978b. Cenozoic coccolith, silicoflagellate, and diatom stratigraphy, Deep Sea Drilling Project Leg 44. In Bensen, W.E., Sheridan, R.E., et al., Init. Repts. DSDP, 44: Washington (U.S. Govt. Printing Office), 807-863.

, 1978c. Cenozoic silicoflagellate and coccolith stratigraphy, northwestern Atlantic Ocean, Deep Sea Drilling Project Leg 43. In Bensen, W.E., Sheridan, R.E., et al., Init. Repts. DSDP, 44: Washington (U.S. Govt. Printing Office), 775-805.

1979. Coccolith and silicoflagellate stratigraphy, northern MidAtlantic Ridge and Reykjanes Ridge, Deep Sea Drilling Project Leg 49. In Luyendyk, B.P., Cann, J.R., et al., Init. Repts. DSDP, 49: Washington (U.S. Govt. Printing Office), 551-581.

, 1981a. Silicoflagellate stratigraphy of offshore California and Baja California, Deep Sea Drilling Project Leg 63, In Yeats, R.S., Haq, B.U., et al., Init. Repts DSDP, 63: Washington (U.S. Govt. Printing Office), 539-557.

, 1981b. Synthesis of silicoflagellate stratigraphy for Maestrichtian to Quaternary marine sediments. In Warme, T.E., Douglas, R.C., and Winterer, E.L. (Eds.), The Deep Sea Drilling Project: A Decade of Progress. Spec. Publ.-Soc. Econ. Paleontol. Mineral., 32:433-444. 
63.

1981c. Cretaceous Arctic silicoflagellates. Geo-Mar. Lett., 1:57-

, 1984. Paleogene paleoceanography of the Arctic Ocean is constrained by the middle or late Eocene age of USGS Core Fl-422: evidence from silicoflagellates. Geology, 12:199-201.

, 1985a. Cenozoic silicoflagellates from Rockall Plateau, Deep Sea Drilling Project Leg 81. In Roberts, D.G., Schnitker, D., et al., Init. Repts. DSDP, 81: Washington (U.S. Govt. Printing Office), 547-563.

1985b. Correlation of late Cretaceous Arctic silicoflagellates from Alpha Ridge. In Jackson, H.R., Mudie, P.J., and Blasco, S.M. (Eds.), Pap.-Geol. Surv. Can., 84-22:125-135.

, 1987. Eocene siliceous and calcareous phytoplankton, Deep Sea Drilling Project Leg 95. In Poag, C.W., Watts, A.B., et al., Init. Repts. DSDP, 95: Washington (U.S. Govt. Printing Office), 395-415.

Cande, S.C., and Kent, D.V., 1992. A new geomagnetic polarity time scale for the Late Cretaceous and Cenozoic. J. Geophys. Res., 97:1391713951.

Deflandre, G., 1934. Nomenclature du squelette des Ebriacées et description de quelques formes nouvelles. Ann. Protist., 4:75-96.

- 1950. Contribution a l'étude des silicoflagellidés actuels et fossiles. Microscopie, 2:117-142.

- 1951. Recherches sur les ébriédiens: paléo-biologie, evolution, systématique. Bull. Biol. Fr. Belg., 85:1-84.

Eldholm, O., Thiede, J., and Taylor, E., 1989. Evolution of the Vøring volcanic margin. In Eldholm, O., Thiede, J., Taylor, E., et al., Proc. ODP, Sci. Results, 104: College Station, TX (Ocean Drilling Program), 1033-1065.

Eldholm, O., Thiede, J., Taylor, E., et al., 1989. Proc. ODP, Sci. Results, 104: College Station, TX (Ocean Drilling Program).

Glezer, Z.I., 1962. K voprosu o filogeneze kremnevykh zhgutikovykh vodoroslei (On the phylogeny of silicoflagellates). Paleontol. Zhurnal, 1:146156.

, 1964. Novye kremnevye zhgutikovye vodorsl:paleogena SSSR. Akad. Nauk. SSSR, Novosti Sistematiki Rasteniy, Otdel. Ottisk, 46-58.

, 1970. Silicoflagellatophyceae. In Gollerbakh, M.M. (Ed.), Cryptogamic Plants of the USSR: Jerusalem (Israel Program for Scientific Translations).

Greuter, W. (Ed.), 1994. International Code of Botanical Nomenclature. Reg. Vegetab., 131:1-120.

Lemmermann, E., 1901. Silicoflagellatae. Ber. Dtsch. Bot. Ges., 19:247271.

Ling, H.Y., 1977. Late Cenozoic silicoflagellates and ebridians from the eastern North Pacific region. In Saito, T., and Ujiie, H. (Eds.), Proc. First Int. Congr. Pacific Neogene Stratigraphy, 1:205-233.

1985. Early Paleogene silicoflagellates and ebridians from the Arctic Ocean. Trans. Proc. Paleontol. Soc. Jpn., 138: 79-93.

Ling, H.Y., McPherson, L.M., and Clark, D.L., 1973. Late Cretaceous (Maestrichtian?) silicoflagellates from the Alpha Cordillera of the Arctic Ocean. Science, 180:1360-1361.

Locker, S., 1974. Revision der Silicoflagellaten aus der Mikrogeologischen Sammlung von C.G. Ehrenberg. Eclogae Geol. Helv, 67:631-646.

Locker, S., and Martini, E., 1986. Silicoflagellates and some sponge spicules from the southwest Pacific, DSDP Leg 90. In Kennett, J.P., von der Borch, C.C., et al., Init. Repts. DSDP, 90: Washington (U.S. Govt. Printing Office), 887-924.

, 1989. Cenozoic silicoflagellates, ebridians, and actiniscidians from the Vøring Plateau (ODP Leg 104). In Eldholm, O., Thiede, J., Taylor, E., et al., Proc. ODP, Sci. Results, 104: College Station, TX (Ocean Drilling Program), 543-585.

Loeblich, A., III, Loeblich, L.A., Tappan, H., and Loeblich, A.R., Jr., 1968. Annotated index of fossil and recent silicoflagellates and ebridians with descriptions and illustrations of validly proposed taxa. Mem.-Geol. Soc. Am., 106:1-319.

Martini, E., 1971. Standard Tertiary and Quaternary calcareous nannoplankton zonation. In Farinacci, A. (Ed.), Proc. 2nd Int. Conf. Planktonic Microfossils Roma: Rome (Ed. Tecnosci.), 2:739-785.

, 1979. Calcareous nannoplankton and silicoflagellate biostratigraphy at Reykjanes Ridge, northeastern North Atlantic (DSDP Leg 49, Sites 407 and 409). In Luyendyk, B.P., Cann, J.R., et al., Init. Repts. DSDP, 49: Washington (U.S. Govt. Printing Office), 533-549.

Martini, E., and Müller, C., 1976. Eocene to Pleistocene silicoflagellates from the Norwegian-Greenland Sea (DSDP Leg 38). In Talwani, M., Udintsev, G., et al., Init. Repts. DSDP, 38: Washington (U.S. Govt. Printing Office), 857-895.

Müller, C., 1970. Nannoplankton-Zonen der Unteren Meeresmolasse Bayerns. Geol. Bavar, 63:107-118.

, 1976. Tertiary and Quaternary calcareous nannoplankton in the Norwegian-Greenland Sea, DSDP, Leg 38. In Talwani, M., Udintsev, G., et al., Init. Repts. DSDP, 38: Washington (U.S. Govt. Printing Office), 823-841.

1979. Calcareous nannofossils from the North Atlantic (Leg 48). In Montadert, L., Roberts, D.G., et al., Init. Repts. DSDP, 48: Washington (U.S. Govt. Printing Office), 589-639.

Myhre, A.M., Thiede, J., Firth, J.V., et al., 1995. Proc. ODP, Init. Repts., 151: College Station, TX (Ocean Drilling Program).

Okada, H., and Bukry, D., 1980. Supplementary modification and introduction of code numbers to the low-latitude coccolith biostratigraphic zonation (Bukry, 1973; 1975). Mar. Micropaleontol., 5:321-325.

Perch-Nielsen, K., 1975. Late Cretaceous to Pleistocene archaeomonads, ebridians, endoskeletal dinoflagellates, and other siliceous microfossils from the subantarctic southwest Pacific, DSDP, Leg 29. In Kennett, J.P., Houtz, R.E., et al., Init. Repts. DSDP, 29: Washington (U.S. Govt. Printing Office), 873-907.

1978. Eocene to Pliocene archaeomonads, ebridians, and endoskeletal dinoflagellates from the Norwegian Sea, DSDP Leg 38. In Talwani, M., Udintsev, G., et al., Init. Repts. DSDP, 38 (Suppl.): Washington (U.S. Govt. Printing Office), 147-175.

, 1985. Silicoflagellates. In Bolli, H.M., Saunders, J.B., and PerchNielsen, K. (Eds.), Plankton Stratigraphy: Cambridge (Cambridge Univ. Press), 811-846.

Schulz, P., 1928. Beiträge zur Kenntnis fossiler und rezenter Silicoflagellaten. Bot. Arch., 21:225-292.

Shaw, C.A., and Ciesielski, P.F., 1983. Silicoflagellate biostratigraphy of middle Eocene to Holocene subantarctic sediments recovered by Deep Sea Drilling Project Leg 71. In Ludwig, W.J., Krasheninnikov, V.A., et al., Init. Repts. DSDP, 71 (Pt. 2): Washington (U.S. Govt. Printing Office), 687-737.

Talwani, M., Udintsev, G., et al., 1976. Init. Repts. DSDP, 38: Washington (U.S. Govt. Printing Office).

von Salis, K., 1993. First Oligocene silicoflagellates from N. Europe (Silstrup, Denmark). Zitteliana, 20:79-86.

Wei, W., and Peleo-Alampay, A., 1993. Updated Cenozoic nannofossil magnetobiochronology. INA. Newsl., 15:15-21.

Ziegler, P.A., 1982. Geological Atlas of Western and Central Europe: The Hague (Shell International Petroleum).

Date of initial receipt: 11 July 1995

Date of acceptance: 24 January 1996

Ms 151SR-102 
This page intentionally left blank. 


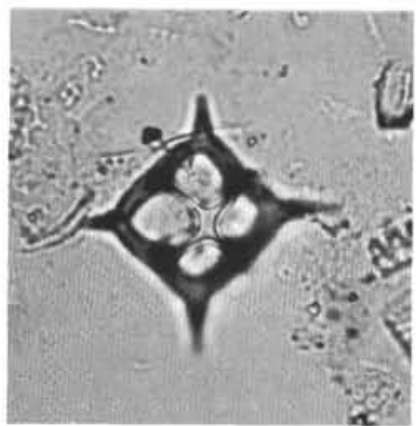

1

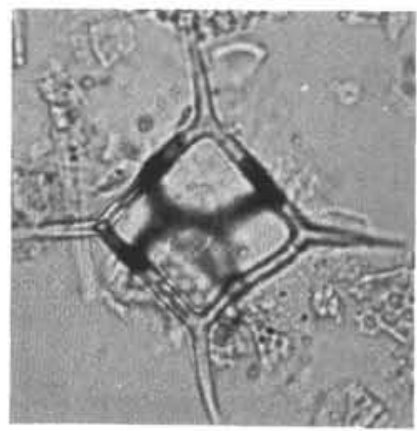

5

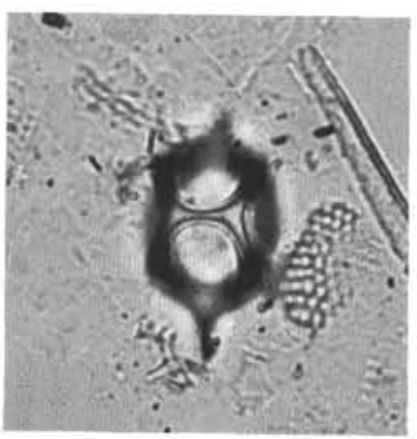

9

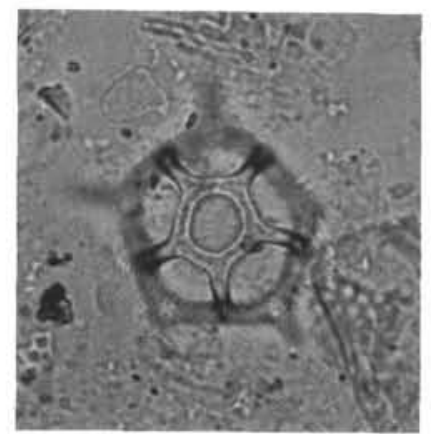

13

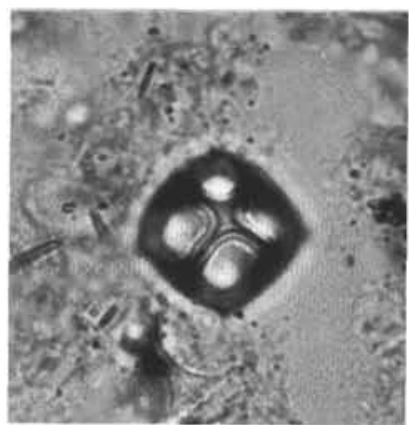

2

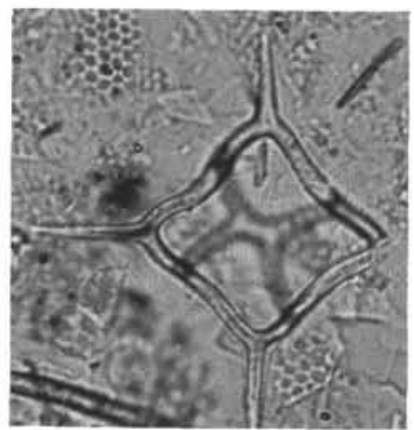

6

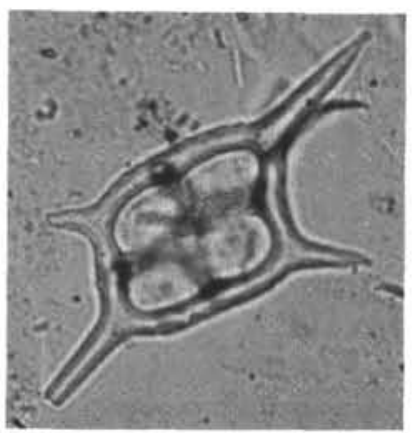

10

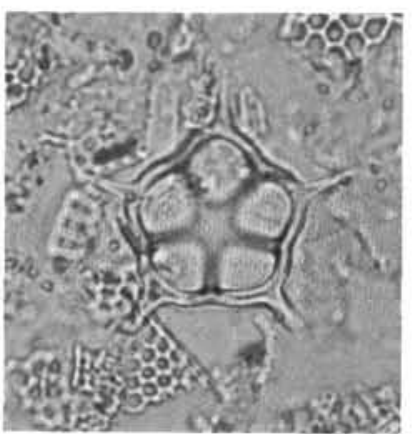

14

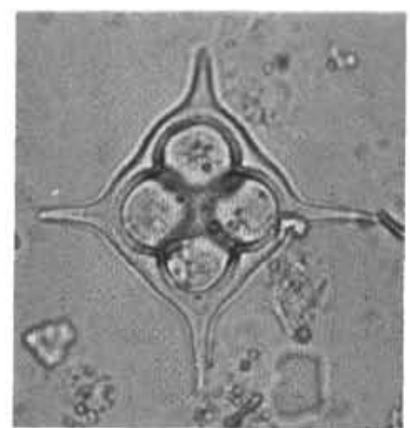

3

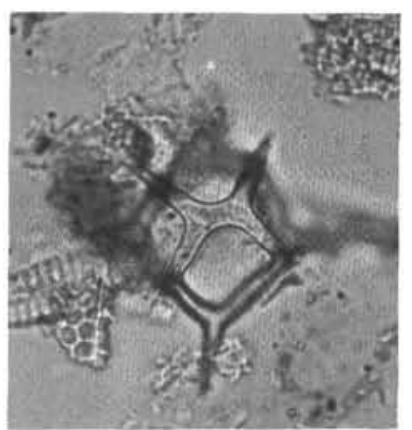

7

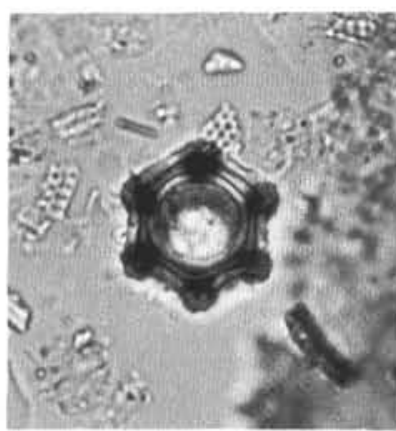

11

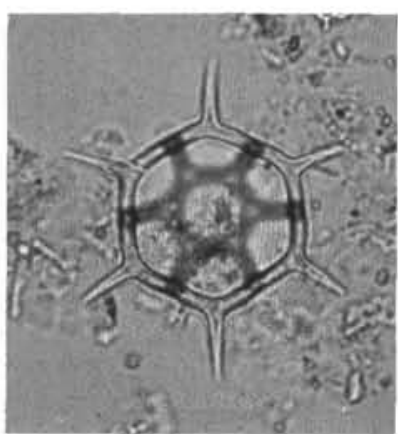

15

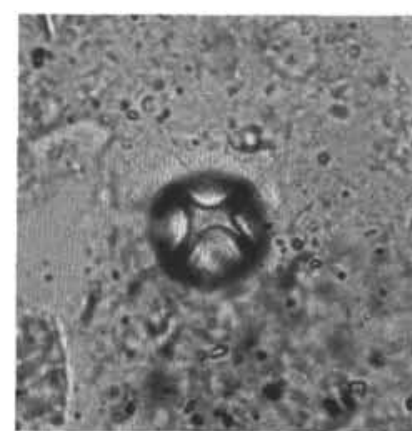

4

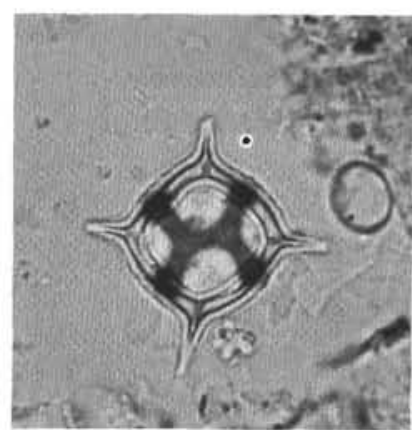

8

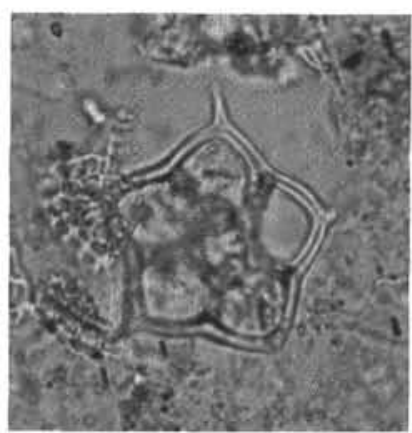

12

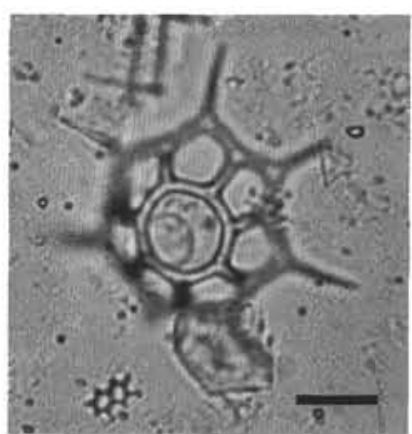

16

Plate 1. Middle to upper Eocene, upper Oligocene, and Miocene-Pliocene silicoflagellates. All specimens magnified $800 \times$, bar $=10$ um. 1. Lyramula furcula Hanna, Sample 151-908A-18X-3, 58-60 cm, Miocene-Pliocene. 2. Cannopilus hemisphaericus (Ehrenberg), Sample 151-908A-23X-4, 59-60 cm, Oligocene. 3. Cannopilus jouseae Bachmann, Sample 151-908A-28X-4, 56-58 cm, Oligocene. 4. Corbisema convexa (Bukry), Sample 151-908A-18X-2, 58-60 cm, Miocene-Pliocene. 5. Corbisema spinosa Deflandre, Sample 151-908A-28X-6, 57-59 cm, Oligocene. 6. Corbisema hexacantha (Schulz), Sample 151-913B25R-2, 114-117 cm, Eocene. 7. Corbisema elata (Glezer), Sample 151-913B-24R-CC, Eocene. 8. Corbisema glezerae Bukry, Sample 151-908A-27X-3, 57-60 $\mathrm{cm}$, Oligocene. 9. Corbisema globulata (Bukry), Sample 151-908A-23X-2, 59-60 cm, Oligocene. 10. Corbisema reducta (Glezer), Sample 151-908A-21X-4, 56-57 cm, Oligocene. 11. Corbisema regina Bukry, Sample 151-913B-26R-6, 110-112 cm, Eocene. 12. Corbisema triacantha (Ehrenberg), Sample 151-908A$24 \mathrm{X}-2,58-59 \mathrm{~cm}$, Oligocene. 13. Corbisema apiculata (Lemmermann), Sample 151-908A-25X-2, 56-60 cm, Oligocene. 14. Corbisema lamellifera (Glezer) subsp. lamellifera, Sample 151-908A-17X-2, 52-54 cm, Miocene-Pliocene. 15. Corbisema katharinae Bukry, Sample 151-913B-26R-5, 113-115 cm, Eocene. 16. Corbisema sp. A, Sample 151-913B-26R-5, 113-115 cm, Eocene. 


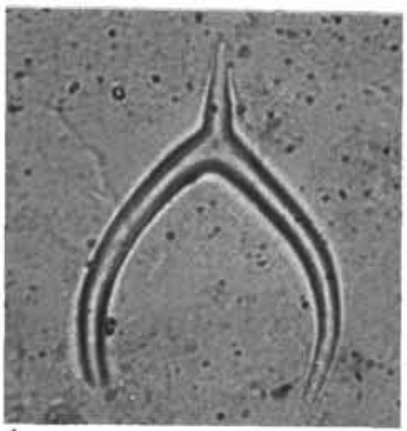

1

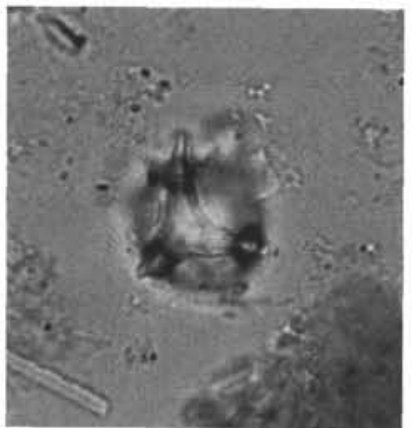

5

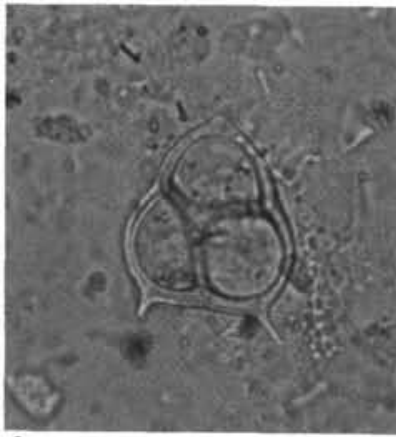

9

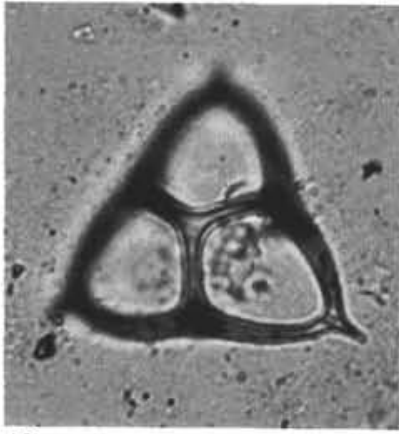

13

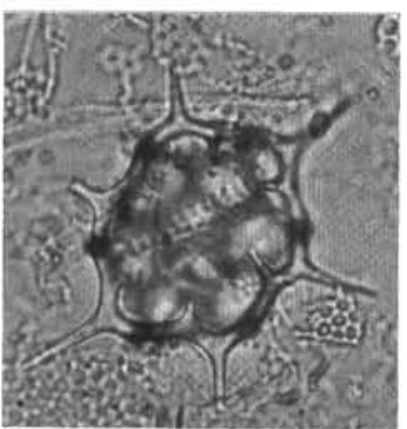

2

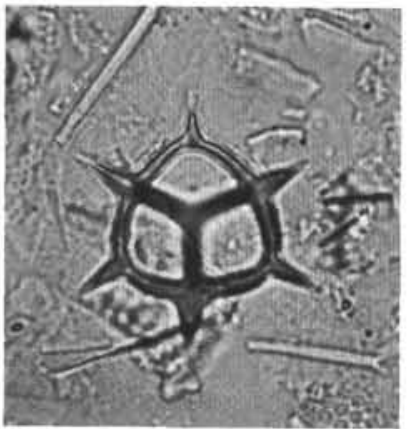

6

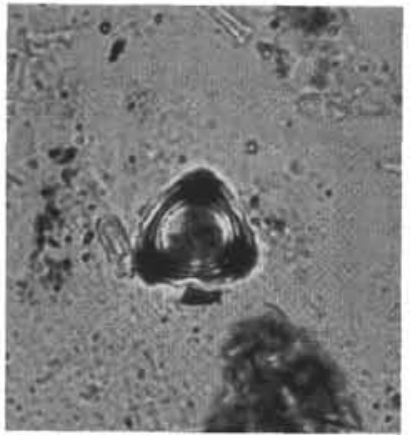

10

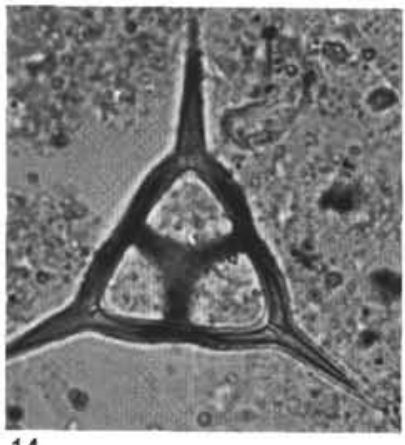

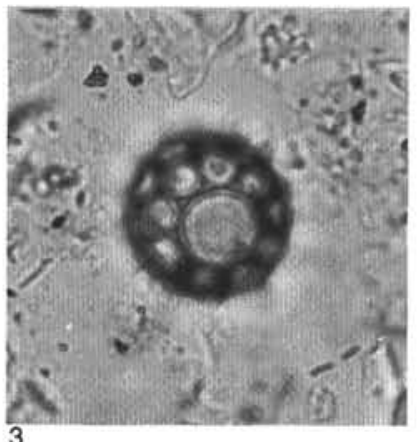

3

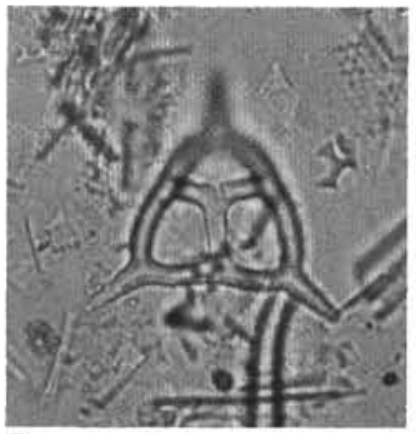

7

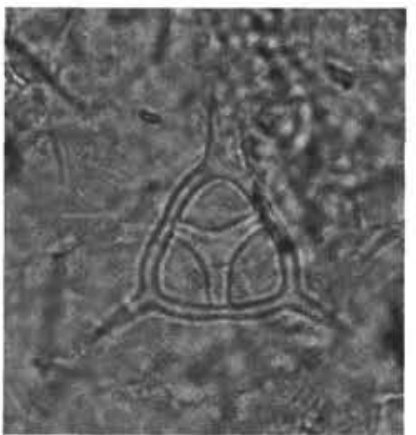

11

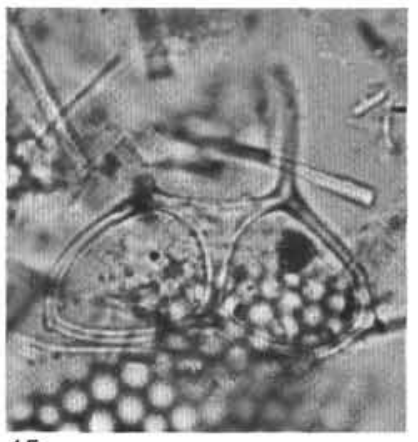

15
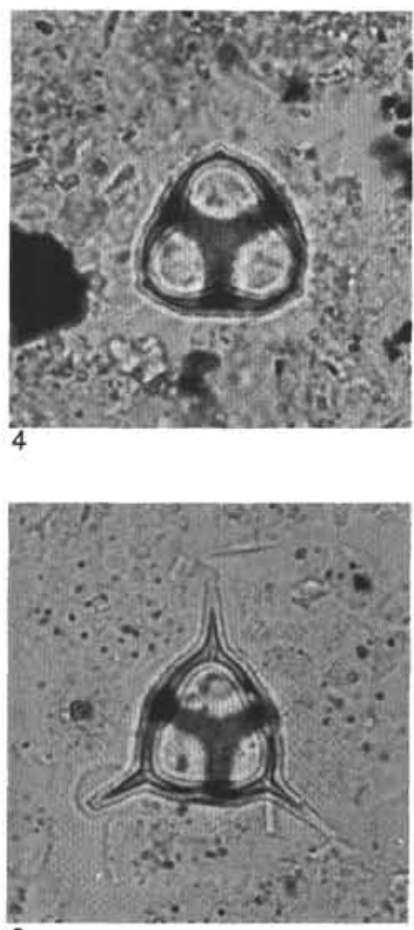

8

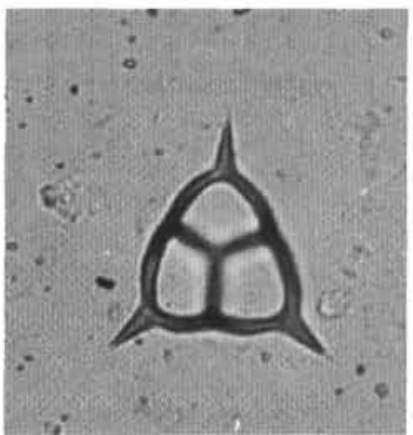

12

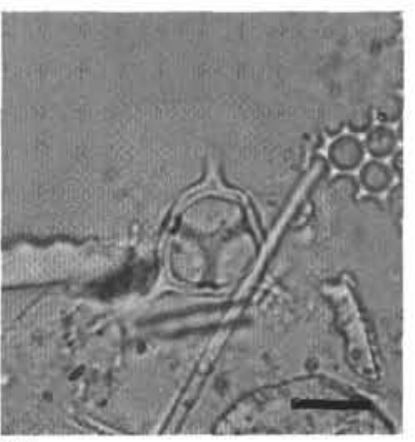

16

Plate 2. Upper Oligocene and Miocene-Pliocene silicoflagellates. All specimens magnified $800 \mathrm{X}$, bar $=10 \mathrm{um}$. 1. Dictyocha carentis (Glezer) subsp. carentis, Sample 151-908A-25X-1, 56-60 cm, Oligocene. 2. Dictyocha carentis subsp. incerta (Glezer), Sample 151-908A-20X-5, 57-60 cm, Miocene-Pliocene. 3. Dictyocha deflandrei Frenguelli, Sample 151-908A-30X-3, 57-59 cm, Oligocene. 4. Dictyocha rotundata Jouse subsp. rotundata, Sample 151-908A-17X-2, 52-54 cm, Miocene-Pliocene. 5. Dictyocha bryonalis Bukry subsp. bryonalis, Sample 151-908A-33X-2, 57-59 cm, Oligocene. 6. Dictyocha bryonalis subsp. A, Sample 151-980A-32X-1, 57-58 cm, Oligocene. 7. Dictyocha frenguellii Deflandre, Sample 151-908A-30X-2, 10-12 cm, Oligocene. 8. Dictyocha precarentis Bukry, Sample 151-908A-32X-4, 58-59 cm, Oligocene. 9. Dictyocha transitoria Deflandre, Sample 151-908A-24X-6, 58-59 cm, Oligocene. 10. Dictyocha obliqua Glezer, Sample 151-908A-22X-4, 57-59 cm, Oligocene. 11. Distephanus antiquus Glezer, Sample 151-908A-28X-5, 57-59 cm, Oligocene. 12. Distephanus norvegiensis Perch-Nielsen, Sample 151-908A-27X-3, 57-60 cm, Oligocene. 13. Distephanus speculum f. pentagonus (Lemmermann), Sample 151-908A-27X-5, 57-60 cm, Oligocene. 14. Distephanus speculum f. schulzii n. nom., Sample 151-908A-34X-3, 57-59 cm, Oligocene. 15. Distephanus speculum (Ehrenberg) f. speculum, Sample 151-908A-25X-4, 55-59 cm, Oligocene. 16. Distephanus speculum f. septenarius (Ehrenberg), Sample 151-908A-24X-4, $58-59 \mathrm{~cm}$. 


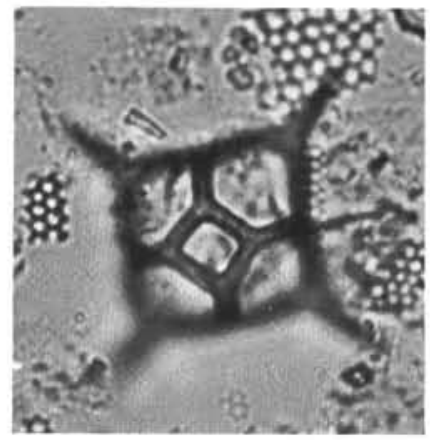

1

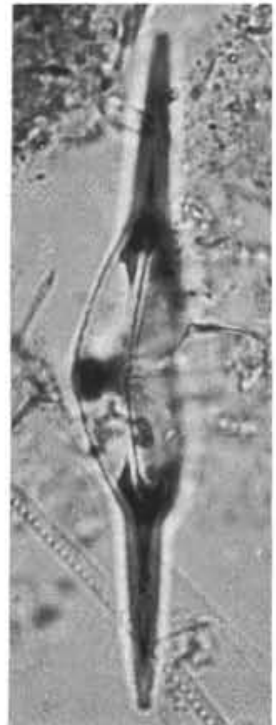

5

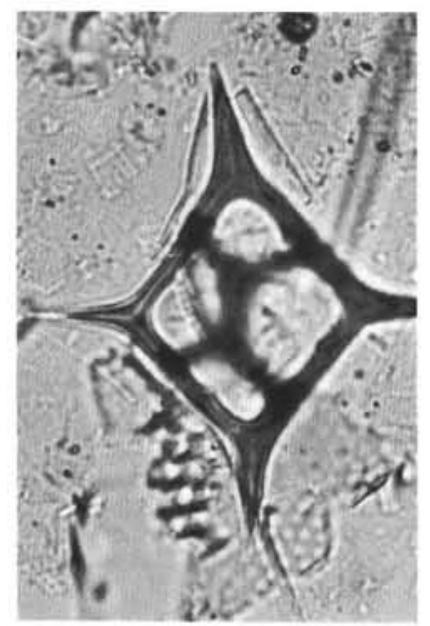

11

6

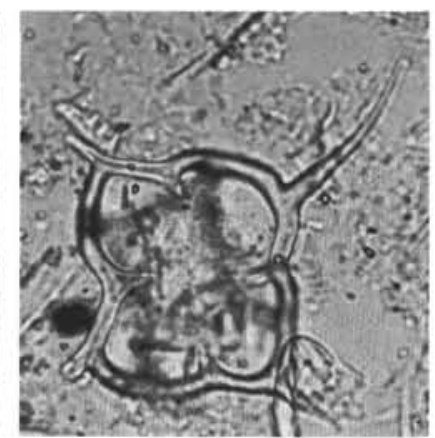

2
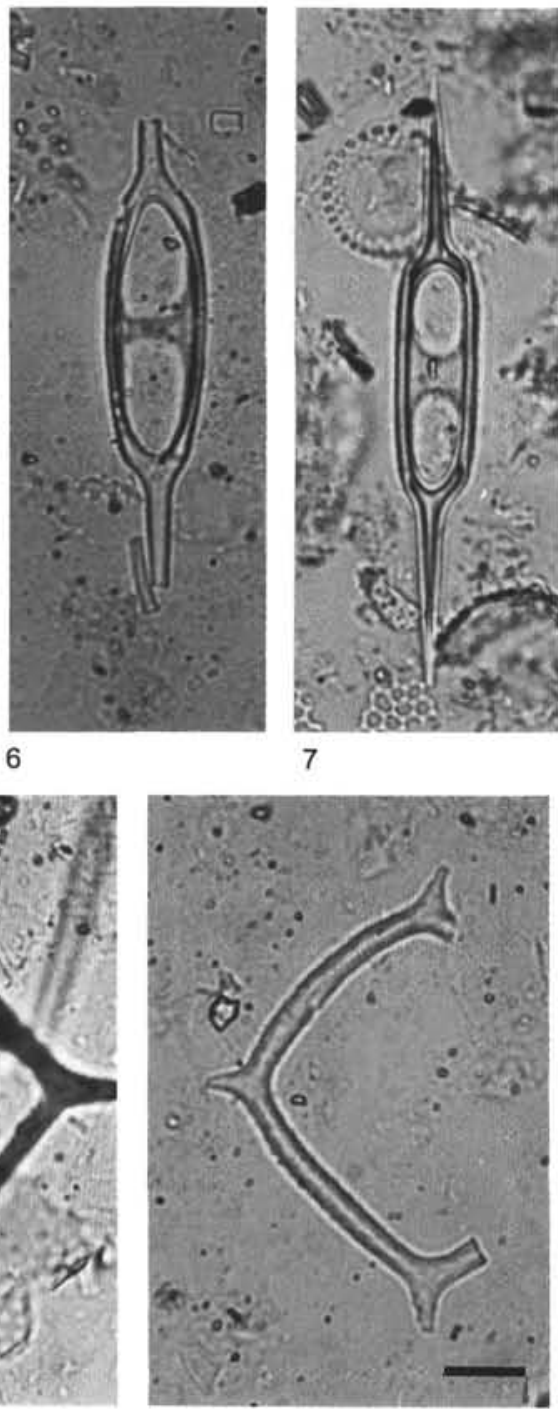

12
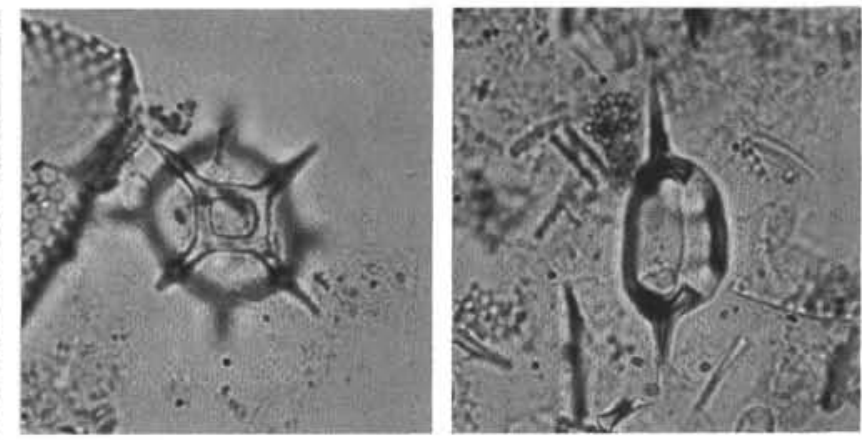

3
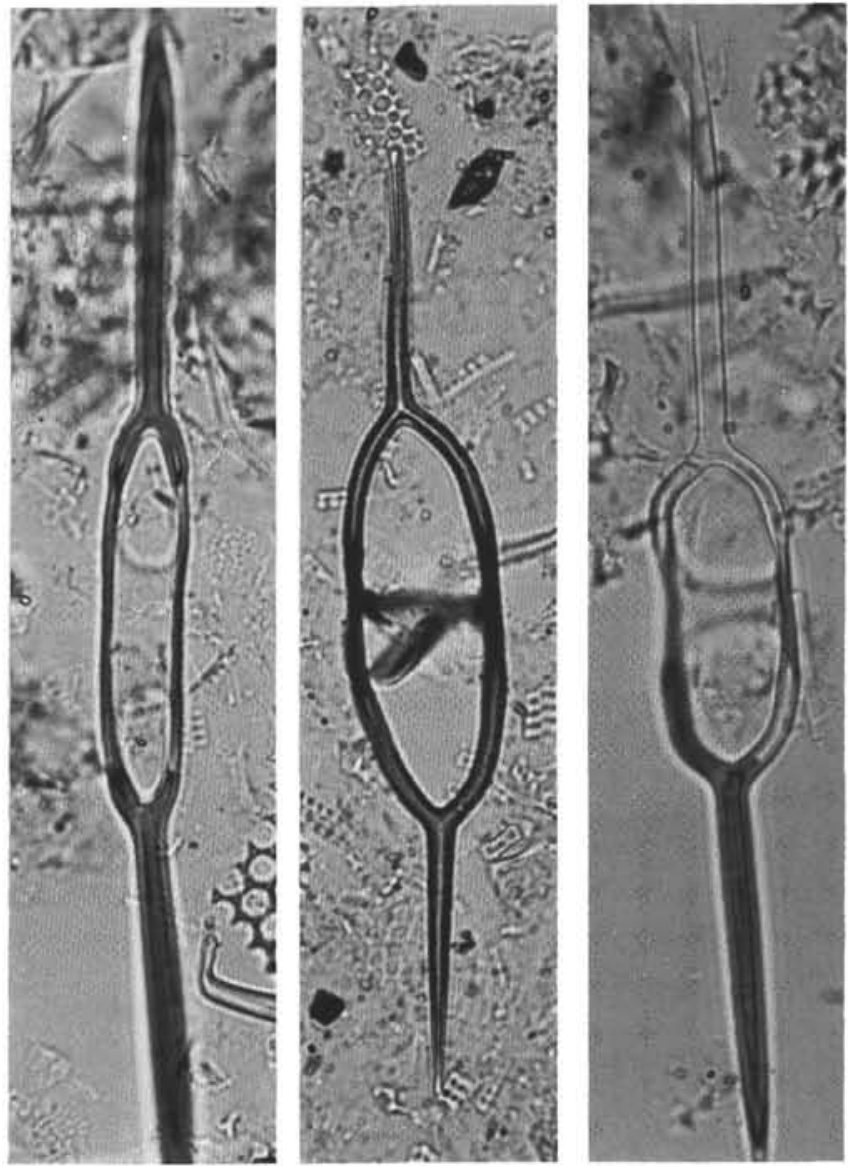

8

9

10

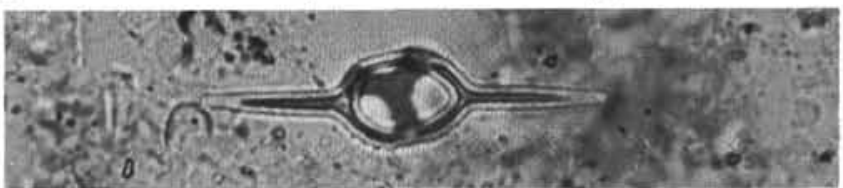

13

Plate 3. Middle to upper Eocene and upper Oligocene silicoflagellates. All specimens magnified $800 \times$, bar $=10$ um. 1. Distephanus crux (Ehrenberg) subsp. crux, Sample 151-908A-21X-3, 57-58 cm, Oligocene. 2. Distephanus crux subsp. A, Sample 151-908A-33X-3, 57-59 cm, Oligocene. 3. Distephanus paulii (Shaw and Ciesielski), Sample 151-908A-25X-4, 55-59 cm, Oligocene. 4. Naviculopsis minor (Schulz), Sample 151-908A-24X-6, 57-59 cm, Oligocene. 5. Naviculopsis aspera (Schulz), Sample 151-908A-26X-2, 57-59 cm, Oligocene. 6. Naviculopsis biapiculata (Lemmermann), Sample 151-908A-24X-1, 58-59 $\mathrm{cm}$, Oligocene. 7. Naviculopsis aff. constricta (Schulz) sensu Perch-Nielsen, Sample 151-908A-34X-2, 57-59 cm, Oligocene. 8. Naviculopsis foliacea Deflandre, Sample 151-913B-26R-2, 113-115 cm, Eocene. 9. Naviculopsis eobiapiculata Bukry, Sample 151-908A-24X-4, 58-59 cm, Oligocene. 10. Naviculopsis constricta (Schulz), Sample 151-913B-26R-5, 113-115 cm, Eocene. 11. Dictyocha sp. A, Sample 151-913B-26R-2, 113-115 cm, Eocene. 12. Mesocena quadrangula Ehrenberg, Sample 151-908A-21X-1, 56-57 cm, Oligocene. 13. Naviculopsis danica Perch-Nielsen, Sample 151-908A-26X-1, 57-59 cm, Oligocene. 


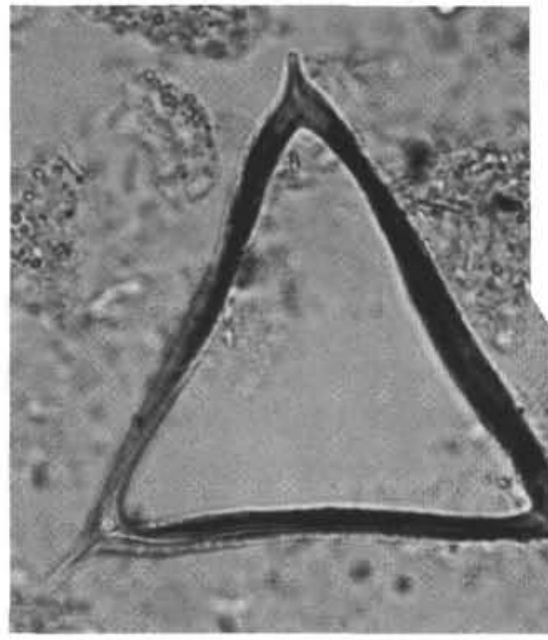

1

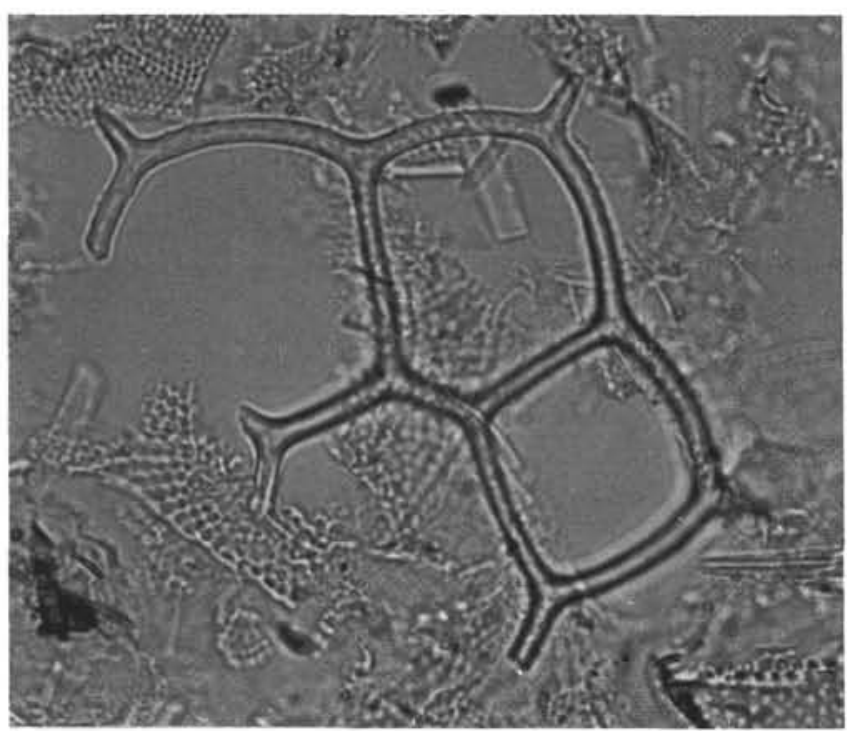

4

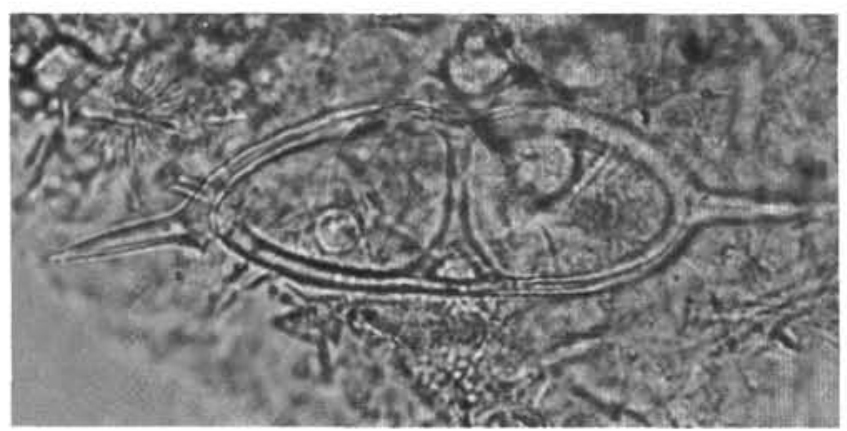

6

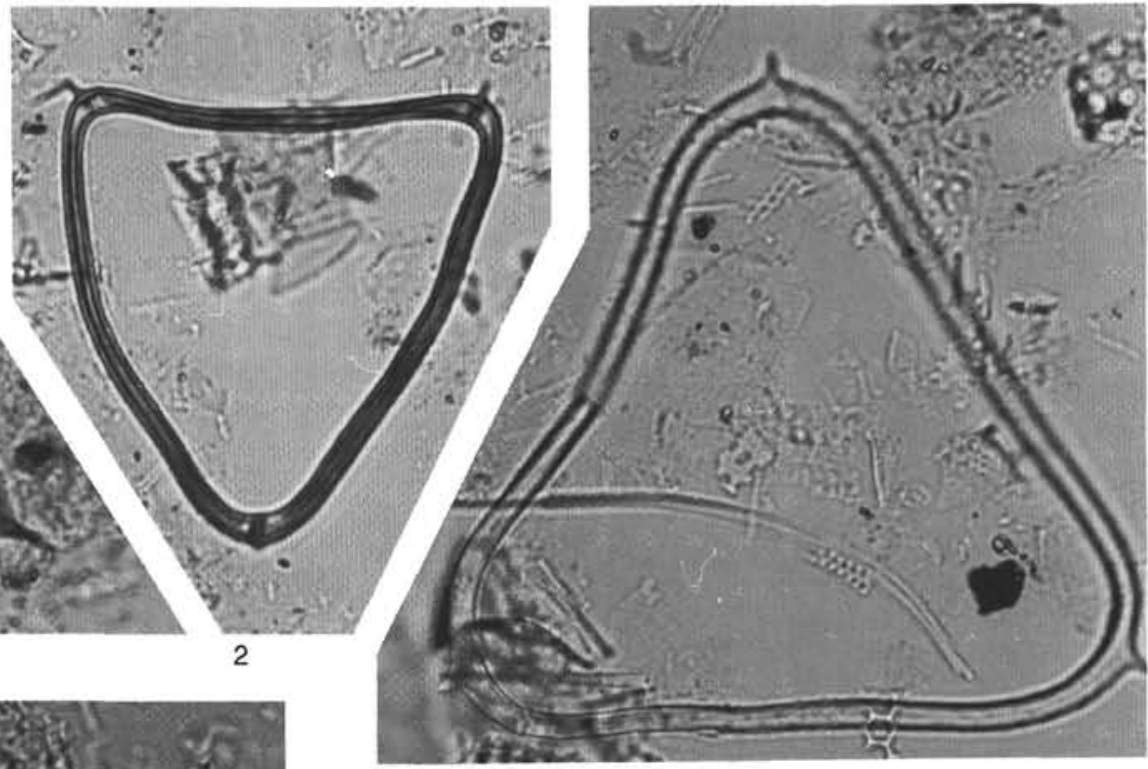

3
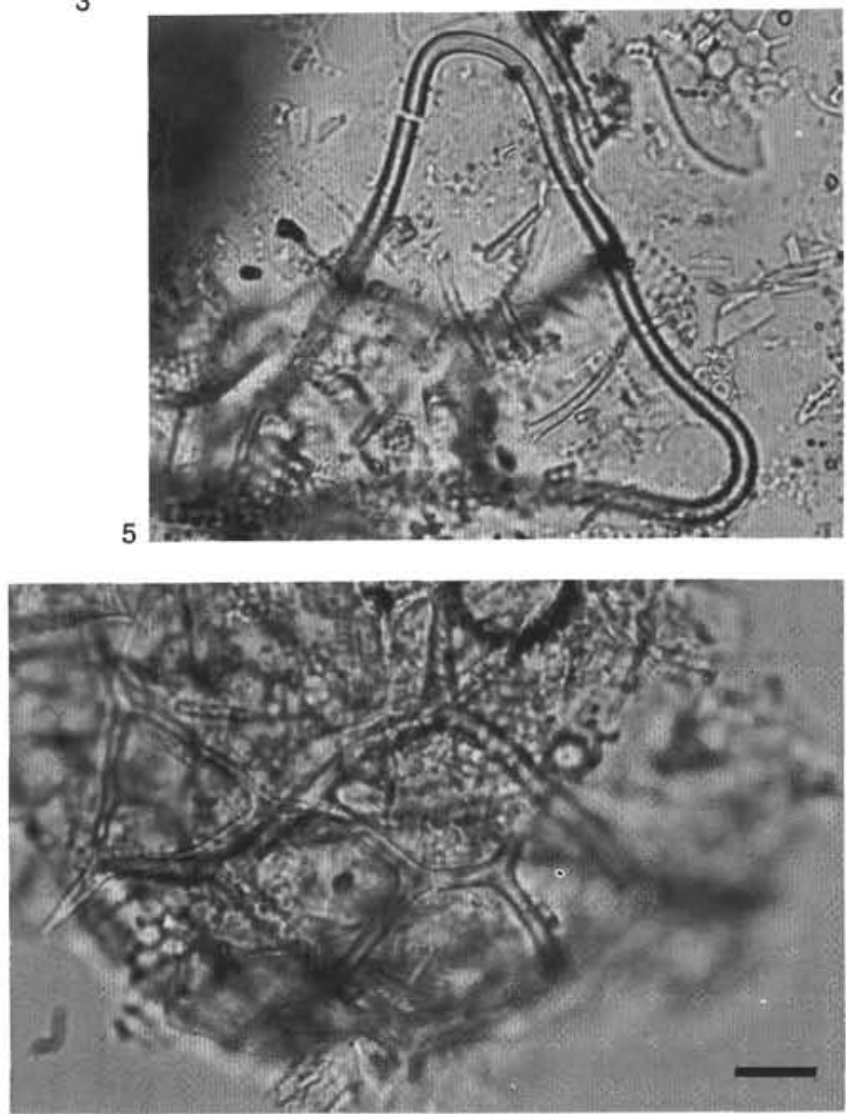

Plate 4. Middle to upper Eocene and upper Oligocene silicoflagellates. All specimens magnified $800 \times$, bar $=10$ um. 1. Septamesocena apiculata subsp. glabra (Schulz), Sample 151-908A-23X-2, 59-60 cm, Oligocene. 2. Septamesocena apiculata (Schulz) subsp. apiculata, Sample 151-913B-25R-6, 113-115 cm, Eocene. 3. Septamesocena apiculata subsp. evexa (Bukry), Sample 151-913B-26R-2, 113-115 cm, Eocene. 4. Dictyocha challengeri Martini and Müller, Sample 151-913B-26R-2, 113-115 cm, Eocene. 5. Corbisema archangelskiana (Schulz), Sample 151-908A-25X-1, 56-60 cm, Oligocene. 6. Dictyocha sp. B, Sample 151-913B-26R-6, 110-112 cm, Eocene. 7. Dictyocha eocaenica (Krotov), Sample 151-913B-27R-1, 113-117 cm, Eocene. 
Plate 5. Middle to upper Eocene, upper Oligocene, middle Miocene, and Miocene-Pliocene ebridians. All specimens magnified 800×, bar $=10$ um. 1. Ammodochium danicum Deflandre, Sample 151-908A-18X-2, 58-60 cm, Miocene-Pliocene. 2. Ammodochium rectangulare (Schulz), Sample 151-908A-23X-1, 59$60 \mathrm{~cm}$, Oligocene. 3. Ammodochium pyramidale Hovasse, Sample 151-908A-30X-1, 57-59 cm, Oligocene. 4. Ammodochium fletcheri Ling, Sample 151-908A27X-2, 57-60 cm, Oligocene. 5. Ammodochium doliolum Hovasse, Sample 151-908A-21X-4, 56-57 cm, Oligocene. 6. Ammodochium sp. A, Sample 151908A-22X-4, 57-59 cm, Oligocene. 7. Pseudammodochium dictyoides Hovasse, Sample 151-913B-26R-1, 113-115 cm, Eocene. 8. Pseudammodochium eximium Deflandre, Sample 151-908A-26X-1, 57-59 cm, Oligocene. 9. Pseudammodochium sp. C, Sample 151-913B-25R-2, 114-117, Eocene. 10. Pseudammodochium sp. A, Sample 151-908A-26X-4, 57-59 cm, Oligocene. 11. Pseudammodochium sp. B, Sample 151-908A-17X-4, 52-54 cm, Miocene-Pliocene. 12. Ammodochium serotinum Locker and Martini, Sample 151-913B-19W-4, 144-148 cm, Miocene. 13. Ammodochium novum Perch-Nielsen, Sample 151-913B24R-CC, Eocene. 14. Hermesinella conata (Deflandre), Sample 151-908A-32X-4, 58-59 cm, Oligocene. 15. Hermesinella paraconata n. sp., holotype, Sample 151-908A-21X-6, 57-58 cm, Oligocene. 16. Hermesinella fenestrata Frenguelli, Sample 151-913B-26R-CC, Eocene. 17. Hermesinella schulzii, Sample 151908A-32X-4, 58-59 cm, Oligocene. 18. Hermesinella cf. transversa Deflandre, Sample 151-908A-18X-1, 58-60 cm, Miocene-Pliocene. 19. Haplohermesinum cornuta (Dumitrica and Perch-Nielsen), Sample 151-913B-24R-CC, Eocene. 20. Haplohermesinum hovassei Locker and Martini, Sample 151-908A-26X3, 57-59 cm, Oligocene. 21. Haplohermesinum sp. A, Sample 151-908A-32X-2, 57-58 cm, Oligocene. 22. Hermesinopsis cf. caulleryi Deflandre, Sample 151913B-25R-1, 114-117 cm, Eocene. 23. Hermesinopsis exigua (Deflandre), Sample 151-908A-24X-1, 58-59 cm, Oligocene. 24. Hermesinopsis? sp. B, Sample 151-913B-25R-4, 112-115 cm, Eocene. 25. Hermesinopsis valida (Deflandre), Sample 151-908A-27X-4, 57-60 cm, Oligocene. 26. Hermesinopsis aplanata (Deflandre), Sample 151-913B-24R-3, 117-120 cm, Oligocene? 27. Parebriopsis symmetrica Dumitrica and Perch-Nielsen, Sample 151-908A-27X-5, 57-60 $\mathrm{cm}$, Oligocene. 28. Falsebria rossica Deflandre, Sample 151-908A-17X-1, 52-54 cm, Miocene-Pliocene. 29. Hovassebria brevispinosa (Hovasse), Sample 151-913B-25R-5, 112-115 cm, Eocene. 30. Spongebria marthae Deflandre, Sample 151-908A-25X-3, 58-62 cm, Oligocene. 


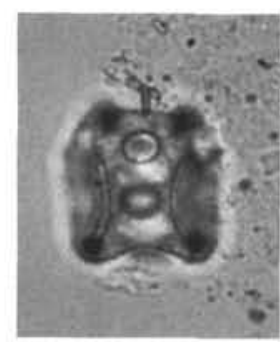

$$
1
$$

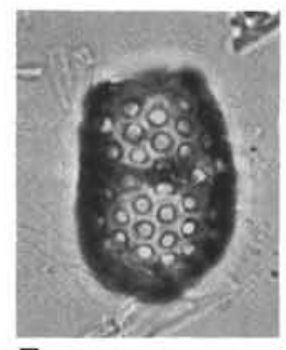

7

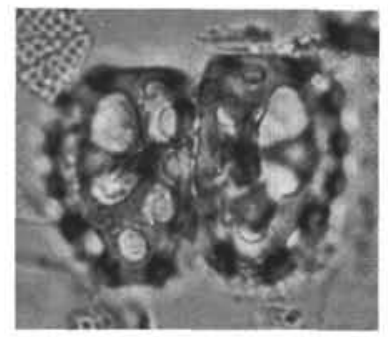

13

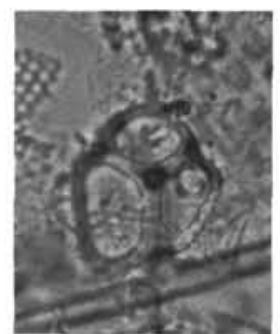

19

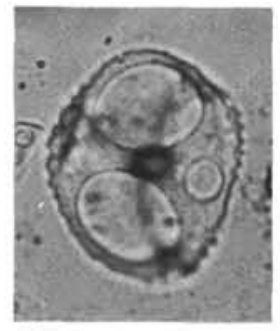

25

20

26

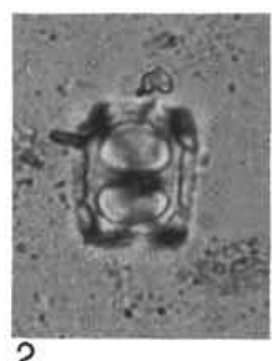

2

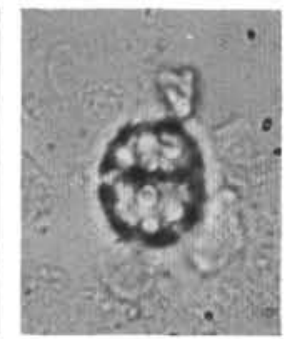

8

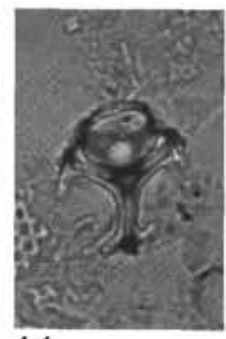

14

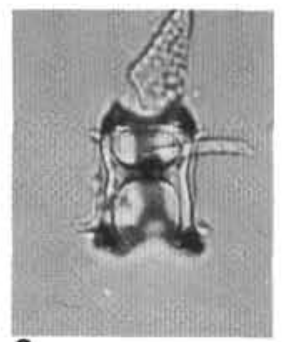

3

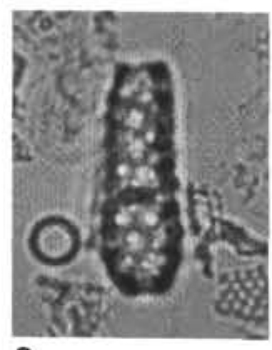

9

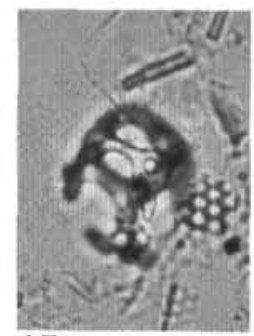

15
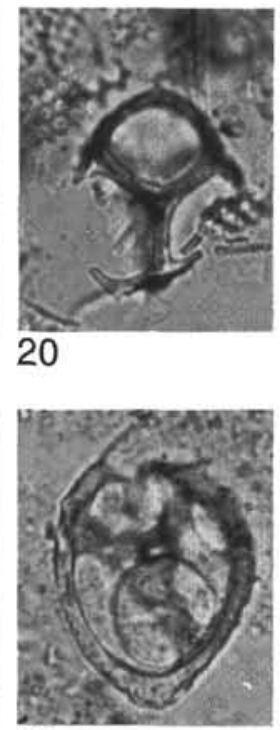

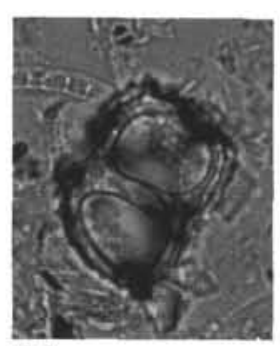

21

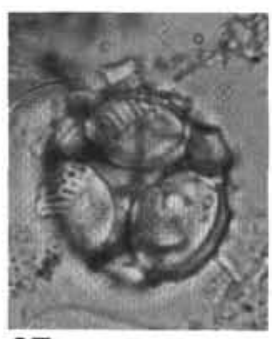

27
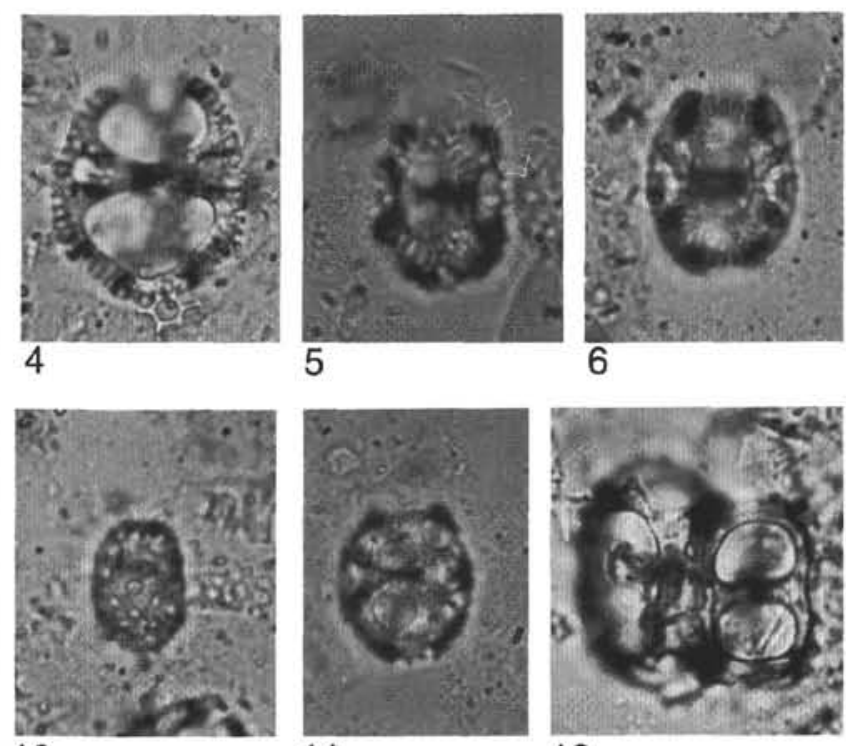

10

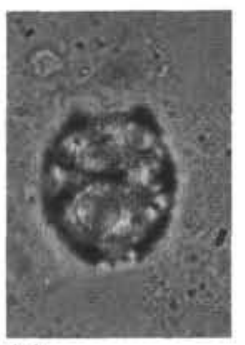

11

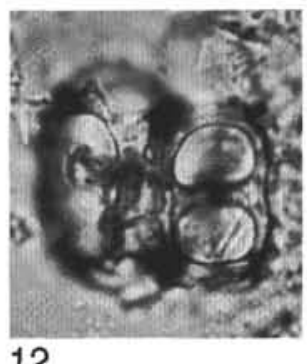

12

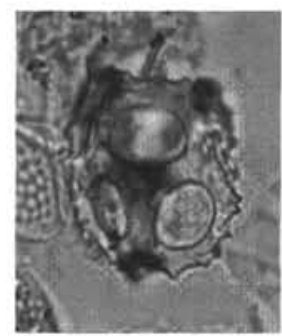

16

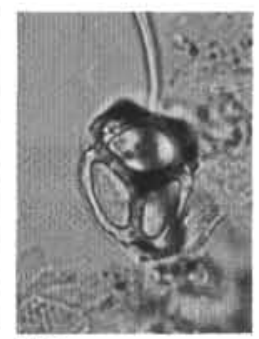

17

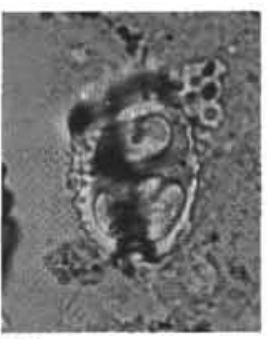

18

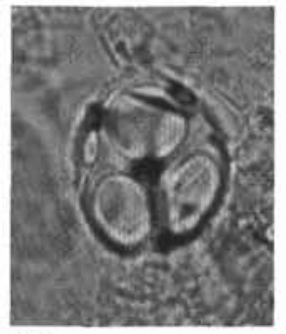

22

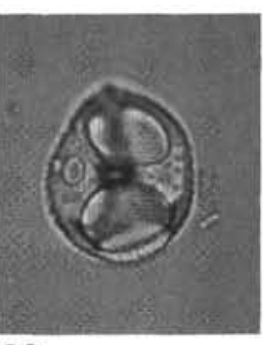

23
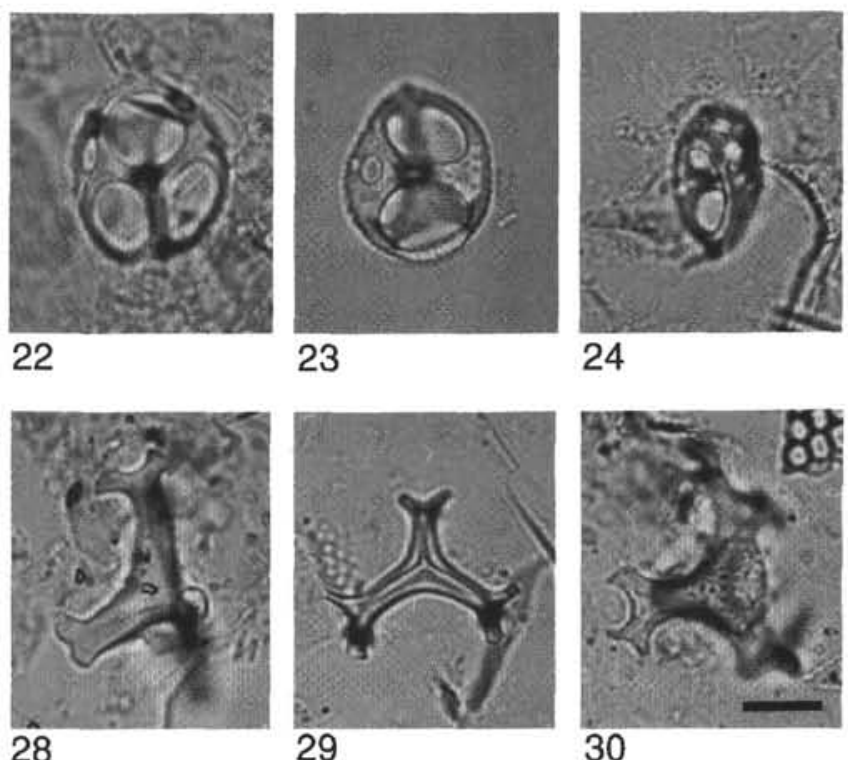

29

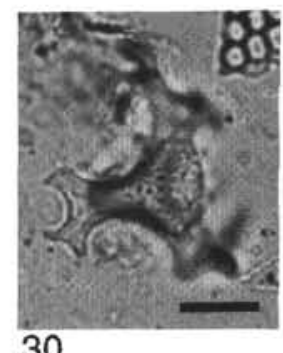



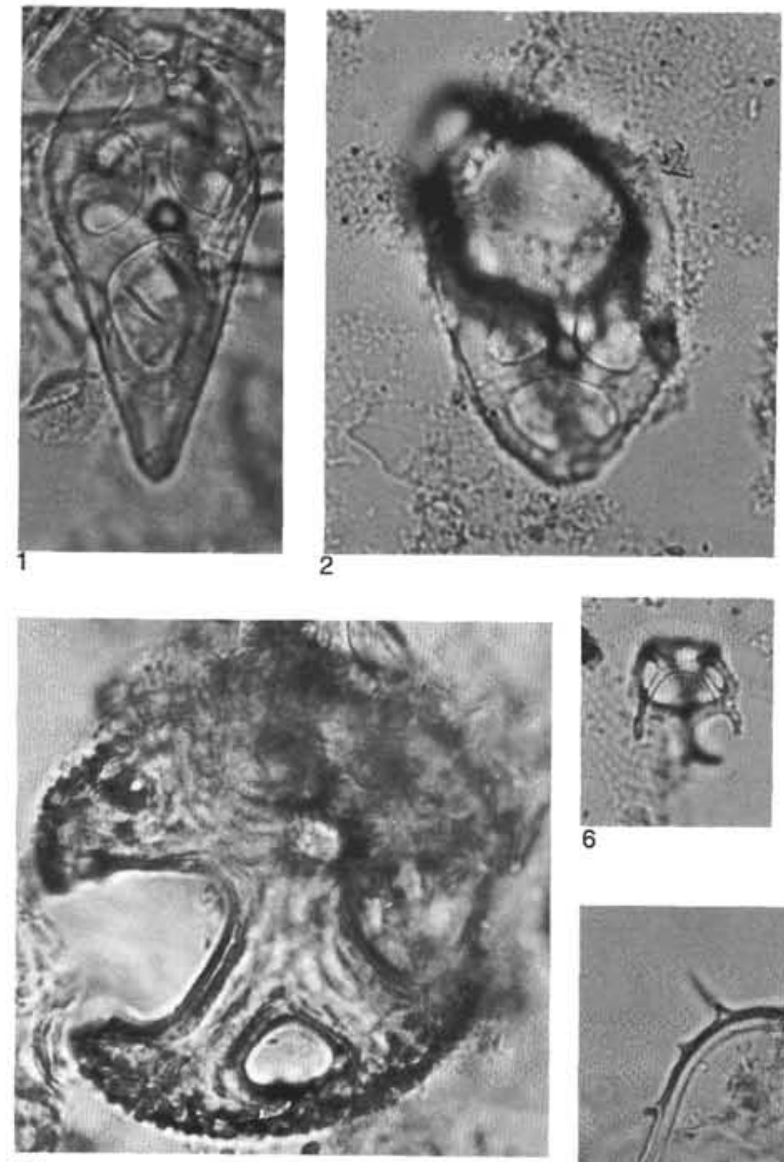

10

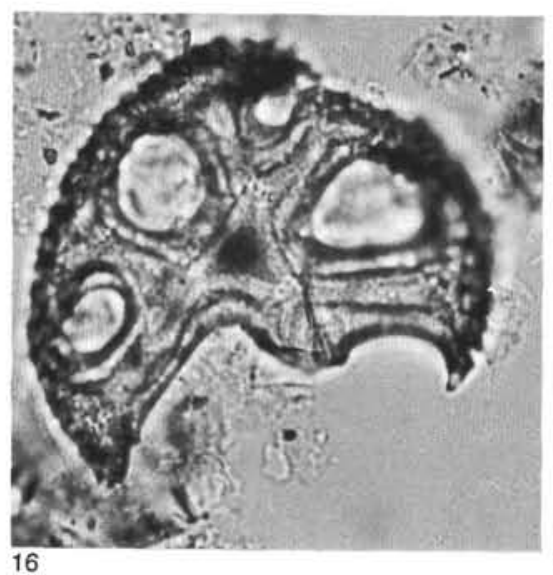

16

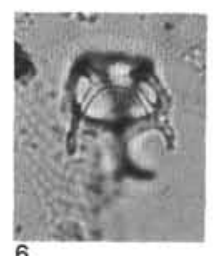

6

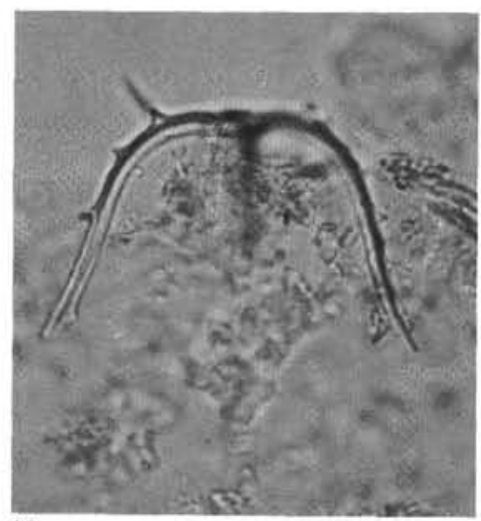

13

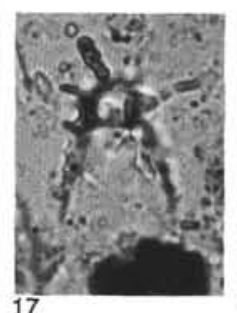

7

18
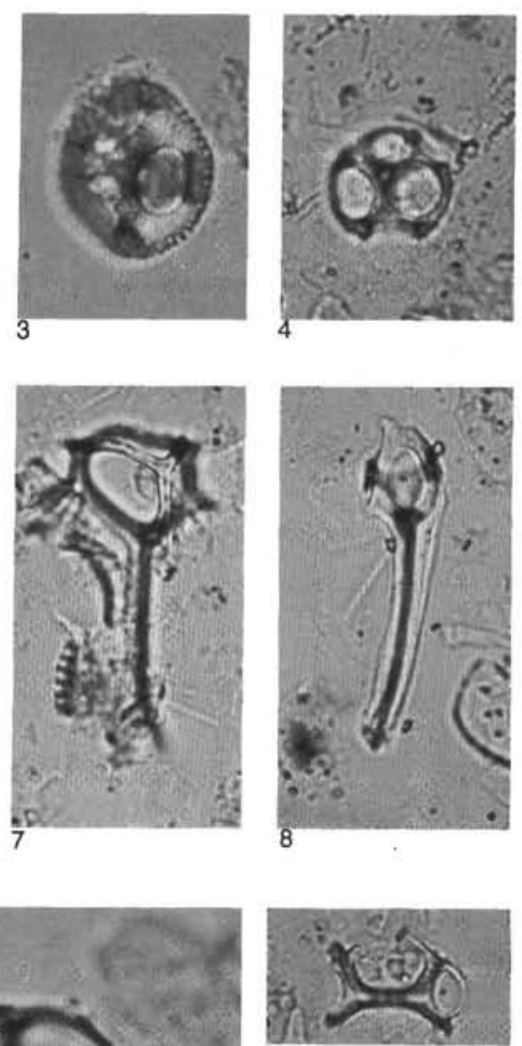

11

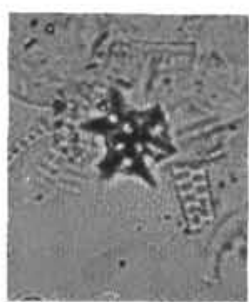

14

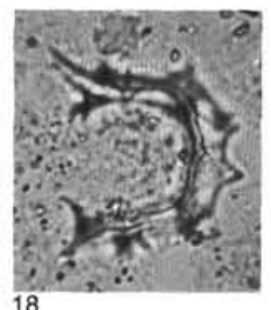

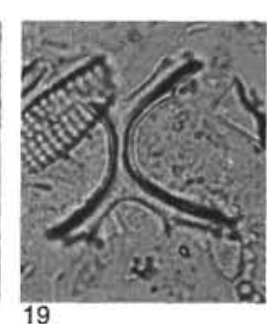

19
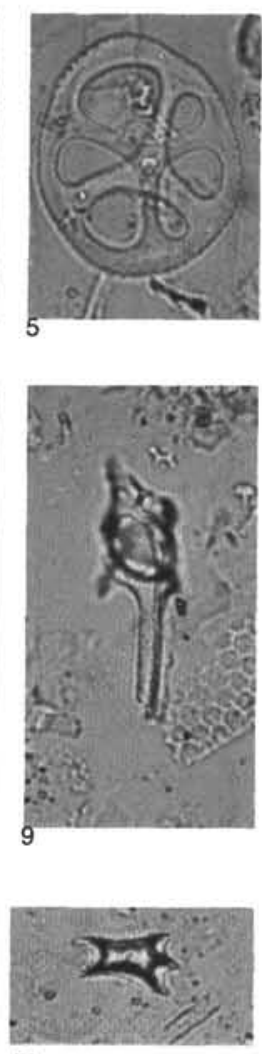

12

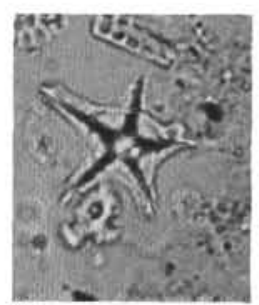

15

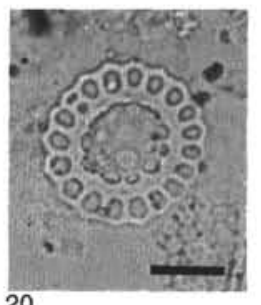

20

Plate 6. Middle to upper Eocene, upper Oligocene, middle Miocene, and Miocene-Pliocene ebridians, actiniscidians, and synuraceans. All specimens magnified $800 \times$, bar $=10$ um. 1. Ebriopsis acuta $\mathrm{n}$. sp., holotype, Sample 151-913B-25R-1, 114-117 cm, Eocene. 2. Ebriopsis antiqua (Schulz), Sample 151-913B-27R4, 113-117 cm, Eocene. 3. Ebriopsis crenulata Hovasse, Sample 151-908A-23X-2, 59-60 cm, Oligocene. 4. Hermesinopsis sp. A, Sample 151-908A-21X-5, 56-57 cm, Oligocene. 5. Ebriopsis sp. A, Sample 151-913B-26R-2, 113-115 cm, Eocene. 6. Hermesinum obliquum Locker and Martini, Sample 151-908A$23 \mathrm{X}-4,59-60 \mathrm{~cm}$, Oligocene. 7. Hermesinum geminum Dumitrica and Perch-Nielsen, Sample 151-908A-33X-2, 57-59 cm, Oligocene. 8, 9. Hermesinum acus n. sp., holotype (8) and syntype (9), Sample 151-908A-28X-6, 57-59 cm, Oligocene. 10. Spongebria curta Locker and Martini, Sample 151-913B-19W-4, 144$148 \mathrm{~cm}$, Miocene. 11. Ditripodium latum Hovasse, Sample 151-908A-24X-2, 58-59 cm, Oligocene. 12. Actiniscus elongatus Dumitrica, Sample 151-908A25X-3, 58-62 cm, Oligocene. 13. Carduifolia lata Hovasse, Sample 151-908A-23X-4, 59-60 cm, Oligocene. 14. Foliactiniscus atlanticus Perch-Nielsen, Sample 151-908A-25X-4, 55-59 cm, Oligocene. 15. Actiniscus pentasterias Ehrenberg, Sample 151-908A-30X-5, 57-59 cm, Oligocene. 16. Spongebria miocenica Locker and Martini, Sample 151-913B-19W-4, 144-148 cm, Miocene. 17. Thranium sp., Sample 151-908A-18X-1, 58-60 cm, Miocene-Pliocene. 18. Carduifolia onopordoides Hovasse, Sample 151-908A-29X-6, 57-59 cm, Oligocene. 19. Carduifolia gracilis Hovasse, Sample 151-908A-29X-5, 57-59 cm, Oligocene. 20. Macrora stella (Azpeitia), Sample 151-908A-26X-1, 57-59 cm, Oligocene. 